\title{
Almanya ve Türkiye'de Karşılaştırmalı Olarak Bakım Hizmetleri: Türkiye'de Bakım Sigortası Kurulmasına Yönelik Bir Öneri ${ }^{1}$
}

\author{
Doç. Dr. Fatma KOCABAŞ² - Dr. Öğr. Üyesi Emre KOL ${ }^{3}$
}

Başvuru Tarihi: 26.08.2019 Kabul Tarihi: 15.10.2020 Makale Türü: Derleme

\section{Öz}

Nüfusun yaşlanması, bütün ülkeler açısından önemli bir sorun olarak karşımıza çıkmaktadır. Yaşlı nüfusun oranı, doğum oranlarındaki azalma ve ortalama yaşam süresinin uzamasına bağh olarak giderek artmaktadır. Türkiye için de, diğer tüm ülkelerde olduğu gibi nüfusun yaş yapısı ile ilgili yapı/durum önemlidir. Günümüzde ülkemizde de yaşlı nüfus giderek artmaktadır. Dolayısıyla yaşlanmaya bağlı olarak bakıma muhtaç olan kişi sayısı gelecek yıllarda artış gösterecek ve buna bağlı olarak yaşlandığında kendine bakamayacak yaşlılar için yapılacak sağllk ve sosyal güvenlik harcamaları ile bakım hizmetlerine duyulan ihtiyaç giderek artacaktır. Yaşlılar ve engelliler başta olmak üzere bakıma muhtaç kişilerin ihtiyaç duyduğu bakım hizmeti, insan sağlı̆̆ı ve ülke ekonomileri açısından hayati bir önem taşımaktadır. Ayrıca bakım hizmetinin ekonomik maliyetlerinin yanında bu hizmeti yerine getirecek nitelikli insan gücünün de varlığı gerekmektedir. Bakıma muhtaç kişiler, gereksinimlerini karşılayacak nitelikli insan kaynă̆ının olmayışı, gelir yetersizliği ve yoksulluk nedeniyle ihtiyaçları olan bakım hizmetlerine erişememektedirler. Bu bağlamda bakım sigortasına duyulan ihtiyaç giderek artmaktadır. Bakıma muhtaçlık da bir sosyal risk olması nedeniyle bu riske karşı da sosyal güvencenin sağlanması gerekmektedir. Ülkemizde sosyal güvenlik hukuku alanında şu an yürürlükte olan 5510 sayılı Sosyal Sigortalar ve Genel Sağlık Sigortası Kanunu kapsamında düzenlenen sigorta kollarına baktı̆̆ımızda bakım sigortasının bulunmadığı görülmektedir. Bu çalışmada, konu ile ilgili literatür ve Almanya uygulaması dikkate alınarak bakım sigortası kurulmasının ülkemiz bakımından önemi ve gerekliliği ortaya konulmuştur.

Anahtar Kelimeler: Bakıma Muhtaçlık, Bakım Sigortası, Bakım Hizmetleri, Yaşlılık, Yaşlı Nüfus

Atıf: Kocabaş, F. ve Kol, E. (2020). Almanya ve Türkiye'de karşılaştırmalı olarak bakım hizmetleri: Türkiye'de bakım sigortası kurulmasına yönelik bir öneri. Anadolu Üniversitesi Sosyal Bilimler Dergisi, 20(4), 283-310.

\footnotetext{
${ }^{1}$ Çalışma etik kurul izni gerektirmemektedir.

2 Anadolu Üniversitesi, İktisadi ve İdari Bilimler Fakültesi Çalışma Ekonomisi ve Endüstri İlişkileri Bölümü, fkocabas@anadolu.edu.tr, ORCID:00000002-8886-8562

3 Anadolu Üniversitesi, İktisadi ve İdari Bilimler Fakültesi Çalışma Ekonomisi ve Endüstri İlişkileri Bölümü, ekol@anadolu.edu.tr, ORCID: 00000002-3242-6925
} 


\title{
Comparative Study on Care Services in Turkey and Germany: A Proposal For the Care Insurance in Turkey
}

\author{
Assoc. Prof. Dr. Fatma KOCABAŞ - Assst. Prof. Dr. Emre KOL
}

\begin{abstract}
Population aging is a significant problem for all nations. The proportion of the elderly population increases due to falling birth rates and increasing mean life expectancy. Although the population of Turkey is young, it will get older. Therefore, the number of people in need of care due to aging will increase over the years. Accordingly, expenditure on healthcare, care services, and social security will also increase. Nursing indigence is a social risk; thus, social insurance must be provided against this risk. Cost-efficient care services are needed for possible problems in this context. Care services needed by the elderly and the disabled, especially those in need of care are vital for human health and national economies. Due to the lack of qualified human resources to meet their needs and global poverty, people in need of care are unable to access the care services they need. In this context, the need for care insurance is increasing. Since the need for care is also a social risk, social security should be provided against this risk. When we look at the insurance branches regulated within the scope of Social Security and General Health Insurance Law (SSGSSK), which is currently in force in the field of social security law in our country, it is seen that there is no long term care insurance. In this study, the necessity of the establishment of care insurance in our country and Germany have been revealed.
\end{abstract}

Keywords: Nursing Indigence, Care Insurance, Care Services, Old Age, Elderly Population 


\section{Giriş}

Günümüzde modern yaşam ve tıp teknolojisindeki gelişmeler neticesinde yaşam süresi uzamakta ve yaşlı nüfus giderek artmaktadır. Tüm dünyada 65 yaş ve üzeri nüfus, diğer tüm yaş gruplarından daha hızlı büyümektedir (United Nations, 2019). Dünyada yaşlı bireylerin sayısının 2030 yılında 1,4 milyara ve 2050 yılında 2,1 milyara, 2100 yılında ise 3,1 milyara ulaşacağı tahmin edilmektedir (United Nations, 2017, s. 11).

Ülkemizde yaşlı nüfus olarak kabul edilen 65 ve daha yukarı yaştaki nüfus, 2014 yılında 6 milyon 192 bin 962 kişi iken son beş yılda \%21,9 artarak 2019 yılında 7 milyon 550 bin 727 kişi olmuştur. Yaşlı nüfusun toplam nüfus içindeki oranı ise 2014 yılında \%8,0 iken, 2019 yllında \%9,1'e yükselmiştir. Yaşlı nüfusun 2019 yılında $\% 44,2$ 'sini erkek nüfus, \%55,8'ini kadın nüfus oluşturmaktadır. Nüfus projeksiyonlarına göre, yaşlı nüfus oranı, 2023 yilında \%10,2, 2030 yilinda \%12,9, 2040 yılında \%16,3, 2050 yllinda \%20,8, 2060 yilinda \%22,6 ve 2080 yılında \%25,6 olacaktır (Türkiye İstatistik Kurumu [TÜİK], 2020a). 2060 yılında genç nüfusun \%11,8'e düşeceği beklenirken (TÜİK, 2020b), yaşlı nüfusun ise 2060 yllında \%22,6 yükseleceği öngörülmüştür (TÜİK, 2020a).

Yaşlılık günümüz toplumlarının her geçen gün etkisi artan önemli sorunları arasında yer almaktadır. Nüfusun yaşlanması nedeniyle, bakıma muhtaçlık riski de giderek daha fazla önem kazanmaktadır (Tufan, 2006, s. 56; aktaran Balcı-Gökçeoğlu, 2017, s. 44). Dünya genelinde yaşlı nüfus yapısına sahip gelişmiş bütün ülkelerde de bakım hizmetleri için yapılan harcamalar artmaktadır. Tüm endüstriyel ulusların bir ortak noktaları vardır; toplumları gittikçe yaşlanmaktadır. Nüfus gelişimine ilişkin tahminlere göre Almanya'da yaşlı kişilerin sayısı (67 yaş ve üstü) 2040 yılına kadar muhtemelen yaklaşık 21,5 milyona yükselecektir. Sosyal devlet olmanın gereği olarak yaşlıların gereksinim duyacağı sağlık ve bakım hizmetlerinin sağlanması gelişmiş ülkelerin temel görevleri arasında yer almaktadır.

Yaşlı nüfusun artmasına bağlı olarak ortaya çıkan ekonomik ve sosyal sorunlar, ülkelerin sağlık harcamalarını ve kamu emeklilik sistemlerini negatif yönde etkileyerek sosyal güvenlik rejimlerinin, işgücü piyasalarının, istihdam ve sürdürülebilir gelişmenin de bundan olumsuz yönde etkilenmesine neden olmuştur (ÖzgülerCanbey, 2006, s. 72; Özgüler-Canbey, 2016, s. 215; Uyanık ve Başyiğit, 2018, s. 273).

Ağören tarafından yapılan çalışmaya göre; 2017-2050 yılları arasında da hem bakıma muhtaç kişi sayısının hem de bu kişilere yapılacak harcamaların artacağı öngörülmektedir. Ağören’in çalışmasında; Türkiye için oluşturulması amaçlanan bakım sigortasına ilişkin olarak bir model önerisinde bulunulmakta ve 2017-2050 yılları itibariyle bakım sigortası kurulması durumunda bir fon oluşturularak, gelir, gider ve optimal prim oranı tahmini yapılmaktadır. Bakım sigortasına yönelik 2017-2050 yılları itibariyle yapılan analizde, bakıma muhtaç kişi sayısının yıllar itibariyle artış göstereceği ve bu artışa bağlı olarak bu kişilere yapılacak harcamaların da artacağı sonucuna ulaşılmıştır (Ağören, 2017, s. 1-4).

Bakıma muhtaçlık da yukarıda ifade edildiği üzere bir sosyal risktir ve bu riske karşı da sosyal güvencenin sağlanmış olması önemli bir zorunluluktur. Bu risk sadece yaşlanma ile ilgili değildir. Hastalık, kaza, işsizlik, engellilik ve ölüm gibi nedenlerle de bakıma muhtaçlık ortaya çıkabilmektedir. Bakıma muhtaç kişi genel olarak, "kronik hastalık, ileri yaşlılık ve/veya ağır engellilik vb. sebeplerle temel gereksinmelerini yerine getirememesinden başkalarının bakım hizmetine ve desteğine ihtiyaç duyandır" (Ayhan, 2014, s. 8-9).

Bakıma muhtaç kişiler giyinme, yeme-içme, beden temizliği, alışveriş gibi temel gereksinmelerinin aile fertleri veya yakınları tarafından karşılanmasına ihtiyaç duymaktadırlar. Dolayısıyla bu kişilerin aile fertleri veya yakınları bu hizmetleri yerine getirirken fiziki, psikolojik ve ekonomik büyük fedakârlıklara katlanmaktadırlar (Ağören, 2017, s. 4). 
Günümüzde, özellikle gelişmiş ülkelerde yaşlı nüfusun artmasına karşılık aile yapısındaki değişmeler, gelir dağılımındaki dengesizlik, kadınların çalışma hayatına katılımlarının artması, doğurganlık oranlarının azalması ve ortalama yaşam beklentisinin uzamasına bağlı olarak muhtaç kişilerin bakım hizmetlerine duydukları ihtiyaç artmaktadır. (Ağören, 2009, s.9). Dolayısıyla bakım sigortası sisteminin kurulması önem arz etmektedir. Günümüzde giderek artan yaşlı nüfusun bakım ihtiyacının karşılanmasına yönelik hizmetlerin, bakım sigortası sistemi içerisinde finanse edilmesi gerekliliği ortaya çıkmıştır (Oğlak, 2008, s. 71-72).

Bakıma muhtaçlık riskine karşı yoksulluk, gelir durumu gibi ayrı sosyal şartlar aranmaksızın bakıma muhtaç duruma gelmiş bütün kişileri sosyal güvenlik sistemine alacak tamamlayıcı bir bakım güvence sisteminin oluşturulması gerekmektedir. Bu nedenle, bakıma muhtaç herkese bakım hizmetlerinden yararlanabileceği sosyal bakım güvence sistemi içinde "Bakım Sigortasının" oluşturulması gerekmektedir (Caniklioğlu ve Ünal, 2011, s. 2285-2286).

Bakım sigortasının amacı; bakıma muhtaç kişilere destek olmak ve bir sosyal risk türü olan bakıma muhtaçlık riskine karşı bir emniyet ve bu riskten doğan maddî zararların (gelir kaybı veya gider artışı) karşılanmasıdır. Buna ilave olarak bakım ihtiyacının karşılanmasını temin etmek ve bakıcı aile fertlerinin bakım yükünü hafifletmek de bakım sigortasının amacı içinde yer almaktadır (Aile ve Sosyal Politikalar Bakanlığı Özürlü ve Yaşlı Hizmetleri Genel Müdürlügü, 2013, s. 2; Metin, 2014, s. 2).

Zorunlu bakım sigortası çok az sayıda ülke tarafından kabul edilmiştir. "Bakım sigortası" uygulaması daha çok gelişmiş ülkelerde bir yandan yaşlanan nüfusun sağlık ihtiyaçlarını gidermek diğer yandan da bakım koşullarını sağlamak amacıyla uygulanmaktadır. Bakım sigortası, primli sistem, primsiz sistem ve bu iki sistemin birleşiminden oluşan karma sistem olarak üç şekilde uygulanmaktadır.

Primli sistem, çalışanın ödediği primlerle finanse edilmektedir. Primli sistemde işçi, işveren, emekli ve devlet memurlarından belirli oranlarda prim kesilerek fona aktarılmaktadır. Bu fon, yaşlılıktaki ihtiyaçlarının karşılanması için gerekli bir tutarı karşılamaktadır. Bu sistemde devlet de, geliri bulunmayan ve muhtaç kimseler için katkıda bulunmaktadır. Yaşlılık döneminde daha çok hizmet almak istenirse, (bir görevlinin sürekli sizinle yaşaması gibi), daha yüksek oranda prim ödemeniz gerekmektedir. Hollanda, Japonya, Kore, Lüksemburg ve Almanya primli sistem içerisinde yer almaktadır (Ağören, 2009, s. 14).

Primsiz sistem sosyal yardım sistemine benzemektedir. Primsiz sistemde, toplanan vergilerle sistemin finansmanı sağlanmaktadır. Bu yolla sistemin finansmanının sağlanarak bakıma muhtaç kişilere hizmet verilen ülkeler arasında Norveç, İspanya, Polonya, Litvanya ve İngiltere gelmektedir (Ayhan, 2014, s. 59-60).

Karma sistem de ise primli ve primsiz sistem bir arada kullanılmaktadır. Bu sistemde bakıma muhtaç kişilerin bakım masrafları, bağımlı çalışanlar ve emeklilerin maaşlarından kesilen primlerle ülke genelinden toplanan vergilerle sağlanmaktadır (Ağören, 2009, s. 14). Karma sistemin kullanıldığı ülkeler arasında da Almanya gösterilebilir.

Ancak, bazı çalışmalarda farklı ülke kümelerini farklı sinıflandırmalarda görmek de mümkündür. Bunun nedeni, bir çalışmada yapılan sınıflandırma sunulan hizmetlerin ve sağlanan desteklerin türüne dayanırken, başka bir çalışmada yapılan sınıflandırma ise ülkelerin uyguladıkları uzun süreli bakım sisteminin özelliklerini (Kurumsal derinliğin boyutu, finansman yöntemi veya finansal açıdan cömertlik) dikkate almaktadır. Başka bir deyişle sınıflandırma da kullanılan kriterlerin farklılığı, ülkelerin farklı sistemler içerisinde yer almasına sebep olabilmektedir. (Ayhan, 2014, s. 61-62). 
Almanya, Belçika, Danimarka, Hollanda vb. ülkelerde bakım sigortası bağlamında öncü olarak nitelendirilebilecek düzenlemeler getirilmiştir. Çalışmamızda da Almanya bakım sigortasını sosyal güvenlik sistemi içerisine ilk alan ülke olması bakımından ayrıntılı olarak ele alınmıştır.

$\mathrm{Bu}$ amaçla yapılan çalışmamızda, ülkemizde de bakıma muhtaçlığın bir risk olarak ele alınıp sosyal güvenlik sistemi içinde değerlendirilmesi ve buna yönelik bir sigorta kolunun kurulmasının gerekli olduğu ortaya konmaya çalışılacaktır. Çalışmamızda ilk olarak Almanya'daki uygulamalara değinilerek, ülkemizde sağlanan bakım hizmetleri ve karşılaşılan sorunlar ile kurulması planlanan bakım sigortasına yönelik öneriler incelenecektir.

\section{Almanya'da Bakım Sigortasının Kapsamı ve Sağlanan Yardımlar Almanya'da Bakım Sigortasının Genel Görünümü}

Günümüzde demografik yapı özellikle gelişmiş ülkelerde, nüfusun yaşlanması şeklinde karşımıza çıkmaktadır. Avrupa dünyanın en yaşlı kıtasıdır. Nüfus projeksiyonlarına göre; 2019 yılı için dünya nüfusunun 7 milyar 604 milyon 656 bin 633 kişi, yaşlı nüfusun ise 703 milyon 711 bin 487 kişi olduğu tahmin edilmiştir. Buna göre, dünya nüfusunun \%9,3'ünü yaşlı nüfus oluşturmaktadır. En yüksek yaşlı nüfus oranına sahip ilk üç ülke sırasıyla \%34,1 ile Monako, \%28,8 ile Japonya ve \%22,7 ile Almanya olmuştur. Türkiye, 167 ülke arasında 66. sirada yer almaktadır (TÜİK, 2020a).

Bu çalışmada incelemek üzere ele aldığımız Almanya'da, OECD ülkeleri arasında Japonya'dan sonra en yaşlı nüfusa sahip ülkelerden birisidir. 2020 yılı itibariyle Almanya'nın nüfusu 83,833,162 kişidir (Demographic of Germany, 2019). Almanya'da, 65 yaş ve üzeri nüfus oranının 2050 yılı itibariyle \%33'e çıkacağı beklenmektedir. Ortalama yaşam süresinin uzaması ve doğum oranlarındaki azalma yaşlı nüfusun giderek artmasına neden olmaktadır (Ayhan, 2014, s. 82; Ranci ve Pavolini, 2015, s. 272-273).

Almanya sosyal güvenlik alanında öncü ülkelerden birisidir. Almanya'da yaşayanların \%85’i standart sağlık güvencesine sahipken geriye kalan kısım ise daha yüksek güvencelerden yararlanmaktadır. Almanya'da nüfusun \%21,5’i 65 yaş ve üzeri yaştadır. Dolayısıyla, Almanya bu oran ile dünyanın en yaşlı üçüncü ülkesidir. 2015 yılında yaşlı bağımlılık oranı olarak tanımlanan 60 yaş üzeri ve üretken olmayan nüfusun 20-60 yaş arası çalışan nüfusa oranı ise \%51.81'dir (Özmete ve Hussein, 2017, s. 18). Almanya'da bakım sigortası kurulmadan önce bakım gereksinimi sağlık (hastalık) sigortası ve sosyal yardımlardan karşılanmaktaydı. Ancak, Almanya'da ortalama yaşam süresi ile bakım ihtiyacı içerisinde bulunan yaşlı nüfus sayısının artması ve sosyal devlet anlayışı ile birlikte bakım sigortasının önemi hissedilmeye başlanmıştır. Alman Yaşlılık Yardımı Derneği (Kuratorium Deutsche Altershilfe) tarafından 1974 tarihinde yayımlanan bir rapor ile bakım sigortasına ilişkin tartışmalar başlamıştır (Metin, 2014, s. 3). Bu nedenle Almanya'da yaşlı bakımına yönelik hizmetler, bakım sigortası aracılığıyla sunularak sosyal güvenlik sisteminin kapsamına alınmıştır (Çağlar, 2015, s. 205; Metin, 2014, s. 2). Kısaca, sosyal güvenlik sistemi içerisinde diğer sigorta kollarına göre kısa bir geçmişi olan bakım sigortası yaşlı nüfusun bakım gereksinimini karşılamak üzere oluşturulmuştur (Çağlar, 2015, s. 92; Geraedts vd. 2000, s. 375-376).

23 Haziran 1994 tarihinde Bakım Sigortası Kanunu'nun kabul edilmesiyle sosyal güvenlik alanında oldukça ileri bir adım atılmıştır. Almanya'da 1994 yılına kadar bakım ağırlıklı olarak ailenin göreviydi ve sadece bakım masraflarını karşılayamayan bireyler gelir-testine dayalı sosyal yardım programlarına başvurabiliyorlardı. Sosyal yardım harcamalarının artması ile başlayan tartışmalardan sonra Almanya zorunlu bakım sigortasını 
sosyal güvenlik sisteminin beşinci ayağ ${ }^{4}$ olarak ilk uygulayan ülkelerden birisidir (European Commission, 2017, s. 1-2)

Bakım Sigortası Kanunu'nun kabulüyle sağlık sigortası kapsamındakiler böylece zorunlu olarak bakım sigortası kapsamına alınmışlardır (Hekimler, 2015, s. 51; Ağören, 2017, s. 16). Toplumun tümünün sigorta kapsamına alınması sosyal devlet olmanın bir gereği olduğunu söylemek yanlış olmayacaktır. Bu Kanunun akabinde Almanya, 1 Nisan 1995 tarihinde evde bakım ve 1 Temmuz 1996 tarihinde de bakım evlerindeki hizmetleri uygulamaya sokarak, bakım sigortasının kapsamını genişletmiştir (Geraedts vd. 2000, s. 375). Almanya'nın bakım sigortası esas olarak bakım ile ilgili harcamaları kapsamaktadır. Bakım sigortası sistemi iki bağımsız kısımdan oluşmaktadır. Bunlar, kamu (sosyal) ve özel bakım sigortasıdır. Her ikisi de benzer yardımların yapıldığı zorunlu sigortalar olarak tasarlanmıştır. Bu iki zorunlu sigorta kolu arasında herhangi bir gelir paylaşımı bulunmamakta ancak bu iki sistemin her biri için yasal bir finansal denge zorunluluğu bulunmaktadır. (Ayhan, 2014, s. 81; European Commission, 2017, s. 1).

Bu Kanun günümüze kadar çok sayıda değişikliklere uğrayarak 2013 tarihinde tam adı "Sosyal Güvenlik 11. Kitap Sosyal Bakım Sigortası" olmuştur. Kısaca Sosyal Bakım Sigortası Kanunu olan bahsi geçen Kanun ile birlikte bakım sigortasının yasal çerçevesi de oturtulmuş oldu. Bu temel Kanunun dışında bakım hizmetlerinin sağlanabilmesi için, kanunu tamamlar nitelikte olan Bakım Süreleri Kanunu 28 Mayıs 2008 tarihinde, Aile Bakım Süreleri Kanunları da ilerleyen dönem içerisinde 6 Aralık 2011 tarihinde kabul edilmiştir. Ancak bu anılan iki kanun doğrudan bakım sigortasına ilişkin hükümler getirmemektedir. (Hekimler, 2015, s. 51-52).

Bakım sigortası, yukarıda da ifade ettiğimiz üzere, kamu ve özel bakım sigortası olmak üzere iki bölüme ayrılmaktadır. Almanya nüfusunun yaklaşık \%90’ı kamu bakım sigortası kapsamına girerken geriye kalan \%10'luk kısım ise özel bakım sigortası kapsamına girmektedir (European Commission, 2017, s. 5). Diğer bir ifadeyle, Alman nüfusunun \%90'ını zorunlu bakım sigortası kapsamında sigortalanmıştır. Nüfusun \%10'u ise tercihini özel bakım sigortasından yana kullanmaktadır. Bununla birlikte, zorunlu bakım sigortası kapsamındaki sigortalıların ayrıca özel bakım sigortası yaptırmaları yönünde bir engelde bulunmamaktadır. Dolayısıyla aynı anda iki sigortadan yararlanması mümkün olduğu gibi, özel bakımın daha çok tamamlayıcı mahiyette olmak üzere yaptırıldığı görülmektedir. Kamu bakım sigortası yaklaşık 73,05 milyon kişiyi, özel bakım sigortası ise 9,22 milyon kişiyi kapsamaktadır. Yardım alanların toplam sayısı, kamu bakım sigortasından ayakta tedavi, 3,141,471 kişi, özel zorunlu bakım sigortası, ayakta tedavi kapsamında 196,930 kişi, kamu bakım sigortasından yatarak tedavi gören toplam 858,284 kişi, özel zorunlu bakım sigortasından yatarak tedavi gören 54,953 kişidir. Bakım sigortasından ayakta ve yatarak tedavi gören kişi sayısı toplam 3,999,755 kişi, özel zorunlu bakım sigortasından tedavi gören toplam 251,833 kişidir. Kamu ve özel bakım sigortasından hizmet alanların toplamı 4,251,638 kişidir (Bundesministerium fur Gesundheit, 2020).

Bakım sigortası, kanuni sağlık sigortasının şemsiyesi altında toplanmıştır. Kanuni sağlık sigortası, bakım sigortasının tüm unsurlarını kapsamaktadır. Bakım sigortası; zorunlu üyelik ve sağlık sigortası tavanlarına göre dağıtım esasına göre yapılan katkılar ile finanse edilmektedir. Kayıtlı kişiler ve işverenler primleri yarı yarıya ödemektedir. Kanuni sağlık Sigortası için uygulanan en yüksek prim limiti 2017 yılı için aylık 4350 Euro olmuştur. 1 Ocak 2017 tarihinden itibaren prim oranı ücretin \%2.55’i olarak uygulanmaktadır. Prim işçiler ve işverenler tarafından eşit oranda ödenmektedir (European Commission, 2017, s. 5). Oysa 2020 tarihi itibariyle zorunlu bakım sigortasının prim tutarı çocuklu sigortalılar için \%3.05, çocuksuz sigortalılar için 0,25 eklendiğinde \%3.30 olarak belirlenmiştir (Bundesministreium für Gesundheith, 2020).

\footnotetext{
4 Almanya'da sosyal güvenlik sisteminin dört ayağı: İşsizlik sigortası, sağlık sigortası, emeklilik sigortası ve kaza sigortasıdır. Ayrıntılı bilgi için bkz: Ayhan, 2014, s. 81.
} 
Bakım sigortası; hastalık, kaza, işsizlik, ölüm vb. risklere karşı yapılan sigortalara benzer şekilde bakım ihtiyacı riskine karşı sosyal güvenliği sağlama ve yaşlılıkta geliri korumak amaciyla oluşturulmuştur. Bu sigorta kolundan sunulan yardım ve hizmetlerde bakıma muhtaç kişilerin insan onuruna yaraşır ve olabildiğince bağımsız bir hayat sürdürmelerinin sağlanması öngörülmektedir. Aynı zamanda, bakım ihtiyacı içinde olan kişilerin olabildiğince uzun süreyle kendi evlerinde ve aile ortamlarında kalmalarını sağlamak, bakım ihtiyacından kaynaklanan fiziksel, mental ve mali baskıların azaltılmasına yardımcı olmak ve kişilerin bakım ihtiyaçları nedeniyle sosyal yardıma muhtaç olmamalarını sağlamak da bu sigorta kolunun oluşturulmasının altında yatan nedenler arasında yer almaktadır (Geraedts vd. 2000, s. 376-377; Metin, 2014, s. 3; Ökem ve Can, 2014, s. 14). Bakıma muhtaç durumda olanlar çeşitli hizmet sağlayıcıların kurum ve hizmetleri arasında seçim yapma hakkına sahiptirler (Metin, 2014, s. 3).

\section{Almanya'da Bakım Sigortasının Kapsamı \\ Bakıma muhtaçık kavramı}

Bakıma muhtaç olmak, bakım sigortasından yararlanabilmenin en önemli koşullarından birisidir. Bu nedenle de öncelikle bakıma muhtaçlık kavramının ortaya konulması gerekmektedir. Bakıma muhtaçlık yeni bir kavram olmamakla birlikte, doğurganlık oranlarındaki azalma ve yaşlı nüfusun artmasına bağlı olarak bu kavram giderek daha önemli hale gelmiştir.

Kaza, hastalık, analık, yaşlılık, malullük, ölüm ve işsizlik gibi sosyal riskler yanında bakıma muhtaçlık da bağımsız ve sosyal güvenliğin kapsamına alınması gereken bir risk olarak karşımıza çıkmaktadır. Bakıma muhtaçlık sorunu, genellikle ileri yaşlarda ortaya çıkan sosyal bir risk olmasına rağmen tüm yaşlarda da kişinin başına gelebilecek bir risktir. Bu nedenle, Almanya' da da bakıma muhtaçlık bir sosyal sorun olarak ele alınarak bakıma muhtaç kişilerin ve ailelerinin desteklenmesini hedef alan yasal düzenlemelere sosyal politikalar içerinde yer verilmeye başlanmıştır. Böylece bakıma muhtaçlık, Bakım Sigortası Kanunu’nun yürürlüğe girmesiyle birlikte yasal çerçeveye kavuşturulmuştur (Caniklioğlu ve Ünal, 2011, s. 2272-2274).

Almanya, 1995 tarihinde yürürlüğe giren Sosyal Bakım Sigortası Kanunu ile bakıma muhtaçlığı ilk kez resmi olarak ele alan ve sosyal güvenlik sistemi içinde yer veren bir ülkedir. Bakım sigortası, bakıma muhtaç yaşlıların bakım hizmetleri ihtiyacını sosyal güvenlik sistemi içinde çözüm bulmaya çalışan önemli bir sosyal koruma mekanizmasıdır. Bakım sigortası, bakım ihtiyacının ortaya çıkması durumunda bakım yükünün ve sorumluluğunun bireyin kendisi ve ailesi dışında devlet ve toplumun da maddi ve sosyal desteklerinin sağlanması anlayışına dayanan önemli bir sosyal politika aracıdır. Bu sigorta kolu bakıma muhtaç yaşlılara sunulacak olan bakım hizmetlerinin yaratacağı gider artışları ve gelir kayıplarına karşı bireyi ve aileyi korumaya yönelik sosyal devlet sistemi anlayışının bir sonucudur (Oğlak, 2014, s. 220-221).

Bakım sigortası ile, bakım hizmetleri içinde yer alan tıbbi ve sosyal bakım, evde bakım, huzurevi, bakımevi, gündüz ve gece bakım, geçici süreli bakım, rehabilitasyon hizmetleri, evde teknoloji kullanımı (telecare-home care), araç-gereç temini, bakım elemanının desteklenmesi ve diğer sosyal destek hizmetleri verilebilmektedir.

Sosyal Bakım Sigortası Kanunu'nun XI'in m.12'e göre bakıma muhtaç olan kişiler sigortadan yararlanmaktadır. Dolayısıyla bakıma muhtaç olmayan bir kimsenin herhangi bir hak elde etmesi mümkün değildir (Hekimler, 2015, s. 61).

Almanya Sosyal Bakım Sigortası Kanunu'nda bakıma muhtaç kişiler, "bedenen, aklen veya ruhen hasta veya engelli olmaları nedeniyle başkalarının yardımına muhtaç olan kişilerdir” ş̧eklinde ele alınmıştır (Ağören, 2017, s. 3; Caniklioğlu ve Ünal, 2011, s. 2267-2297; Cengiz, 2018, s. 28). Dolayısıyla bağımsızlıkları veya yetenekleri sağlıklarından ya da yaşlılıklarından ötürü kısıtlanmış olup da başkalarının desteğine ihtiyaç duyan kişiler 
bakıma muhtaçtır. Günlük hayatta beden temizliği, tuvalet ihtiyacı, yemek hazırlayıp yemek; yürümek, alışveriş yapmak, ev işleri vb. yaşamını devam ettirebilmesi için gerekli olan hareketleri devamlı olarak, ya da en az 6 ay süreyle yapamayan ve bu hareketleri yapabilmek için büyük ölçüde başkalarının desteğine ihtiyaç duyanlar bakıma muhtaç sayılırlar. Dolayısıyla yemek hazırlamak ve yemek yeme, yıkanmak, çamaşır-bulaşık yıkamak gibi alışılagelmiş ve yaşamın sürdürülebilmesi için gerekli olan günlük olağan ve sürekli tekrarlanan hareket ve işlerde yardıma muhtaç olanlara verilen hizmetler, bakım hizmetlerini oluşturmaktadır (Aile ve Sosyal Politikalar Bakanlığı Özürlü ve Yaşlı Hizmetleri Genel Müdürlüğü, 2013, s. 8). Bakıma muhtaç kişilerin aile fertleri veya yakınları, bu ihtiyaçlarının karşılanması için yardımcı olmakta ve bundan dolayı da fiziki, psikolojik ve ekonomik açıdan büyük fedakârlıklara katlanmaları gerekmektedir.

Bakıma muhtaç olan kişiler bu ihtiyaçlarının karşılanması için Bakım Sigortası Kasasından (Pflegekasse) yardım talep edebilirler (Taşçı, 2010, s. 190). Sigortalının bakıma muhtaç olup olmadığı, Bakım Sigortası Kasasına başvurması üzerine uzmanlarca belirlenir.

\section{Bakım sigortası kapsamına girenler}

Bakıma muhtaçlık, hayatın doğal akışı içinde ortaya çıkabileceği gibi, bir hastalık ya da bir kaza sonucunda da kendiliğinden ortaya çıkabilmektedir. Almanya'da bu sigorta tüm toplumu kapsamaktadır. 1994 yllında, mevcut sağlık sigortası kapsamındaki her birey aynı zamanda bakım sigortası kapsamına alınmış ve 1995 yılından itibaren de bakım sigortası için prim ödemeleri başlamıştır. Yaş, gelir ve mal varlığına bakılmaksızın, tüm sigortalılar hizmetlerden yararlanabilmektedir. Nitekim Sosyal Bakım Sigortası Kanunu'nun XI'in 20. maddesinin 1. ve 3. fikraları, bakım sigortasının kapsamına kimlerin dâhil edileceğini düzenleme altına almıştır. Bu maddeye göre, kanuni sağlık sigortası kapsamında olan her birey aynı zamanda doğrudan bakım sigortasının da kapsamındadır. Sigortalının çalışmayan eşi ve hak sahibi çocukları ayrıca bir prim ödemeden bakım sigortası kapsamına girerken emekli maaşı alanlar da sigortanın kapsamında yer almaktadır (Hekimler, 2015, s. 52).

Sistem esas itibariyle sağlık sigortasına bağlanmakla birlikte, kanuni sağlık sigortası kapsamında olmayan ve bakıma muhtaç olan kişiler de Almanya'da ikamet etmeleri ve kanuni veya özel sağlık sigortası kapsamında olmamaları şartıyla bakım sigortasından yararlanmaktadırlar (Hekimler, 2015, s. 53).

Sigortalının, sürekli ikametleri Almanya'da olan eşi ve çocukları da bakım sigortası kapsamında yer almakta olup, sigorta hizmetlerinden yararlanırlar. Almanya'da sigortalanıp başka bir AB ülkesinde yaşayanlar sadece nakit yardımı alma hakkına sahiptir (Ökem ve Can, 2014, s. 21)

Almanya'da bakım sigortası daha önce de ifade ettiğimiz üzere; kamu ve özel olarak iki kısma ayrılmaktadır. Almanya nüfusunun yaklaşık \%90'ı kamu bakım sigortası kapsamında yer alırken geriye kalan \%10'u ise özel bakım sigortası kapsamına girmektedir. Dolayısıyla bakım sigortası neredeyse tüm nüfusu kapsamaktadır. Kendi işinde çalışanlara, devlet memurlarına ve aylık geliri yüksek olan bireylere özel bakım sigortasını seçme hakkı tanınmıştır (Ağören, 2009, s.17). Bu bireyler, kamu bakım sigortasından yararlanmak istemedikleri durumda zorunlu olarak özel bakım sigortası kapsamına girmektedirler. Özel bakım sigortası da minimum kamu sigortası hizmet/yardım paketlerine denk planlar sunmak zorundadır. Ayrıca, gönüllülük esasına dayalı olarak isteyen bireyler için ek bakım sigortası planları da mevcuttur (Ayhan, 2014, s. 85; European Commission, 2017, s. 5).

Alman bakım sigortası, bakım kasası aracılığıyla bakım gereksinimi duyan yaşılırın içinde bulundukları duruma göre bir kademelenmeye tabi tutmaktadır. Temel ölçüt olarak da bakıma muhtaçlık derecesi alınmaktadır. 
2017'den itibaren bakıma muhtaçlık dereceleri Tablo 1'de gösterilmiştir.

Tablo 1.

Bakıma Muhtaçlık Derecelerinin Sınıflandırılması

\begin{tabular}{|c|c|}
\hline Bakıma Muhtaçlık Dereceleri & \\
\hline Bakıma Muhtaçlık Derecesi I & Bağımsızlığın az kısıtlanması \\
\hline Bakıma Muhtaçlık Derecesi II & Bağımsızlığın oldukça kısıtlanması \\
\hline Bakım Muhtaçlık Derecesi III & Bağımsızlığın çok kısıtlanması \\
\hline Bakım Muhtaçlık Derecesi IV & Bağımsızlığın çok fazla kısıtlanması \\
\hline Bakıma Muhtaçlık Derecesi V & Bağımsızlığın aşırı kısıtlanması ve özel ihtiyaçların birleşimi \\
\hline
\end{tabular}

Bakıma muhtaç kişinin hangi bakım grubuna alınacağına Hastalık Kasası Sağlık Servisi karar vermektedir (Özmete ve Hussein, 2017, s. 19). Sağlık sigortasının tıbbi hizmet biriminin (Medizinischen Dienst der Krankenversicherung-MDK) uzmanı, ilgili bakım ödeneğinin miktarına karar verir. Bakıma muhtaçlık derecesinin belirlenmesi SGB XI (Sosyal Kanun) 15. Bölümde belirtilmiştir. Bakım durumunda, bakıma muhtaç kişi veya yakınları bakım sigortasına bakım ödeneği veya bakım yardımı başvurusunda bulunur. Bakım ihtiyacının derecesini belirlemek için uzman, ilgili kişiyle kişisel bir görüşme yapar. Bu görüşme evde, hastanede veya bakım tesisinde gerçekleşmektedir. Bu sohbette genellikle ilgili kişinin aile üyeleri de bulunur. $\mathrm{Bu}$ görüşme sırasında, bir puanlama sistemi (değerlendirme aracı) yardımıyla bakıma duyulan ihtiyacın derecesi belirlenir. Sonuç bir uzman raporuna kaydedilir ve daha sonra bakım sigortasından yararlanmak üzere kullanılır (Pflegetagegeldversicherung, t.y.).

2017 yılından bu yana, sosyal bakım sigortasında aşağıdaki şekilde tanımlanan 5 bakım seviyesi bulunmaktadir:

- Bakım düzeyi I: Bağımsızlık veya becerilerde düşük düzeyde bozulma (12,5'ten 27'nin altına toplam puan),

- Bakım düzeyi II: Bağımsızlık veya becerilerin önemli ölçüde bozulması (27'den 47,5'in altına toplam puan),

- Bakım seviyesi III: Bağımsızlık veya becerilerin ciddi şekilde bozulması (47,5'ten 70 toplam puana kadar),

- Bakım seviyesi IV: Bağımsızlık veya becerilerin en ciddi bozukluğu (70'ten 90'ın altına toplam puan),

- Bakım düzeyi V: En ciddi bağımsızlık bozuklukları veya hemşirelik bakımı için özel talepler içeren beceriler (90'dan 100'e toplam puan).

Bakım seviyesinin 2017 yılında beş basamağa çıkarılması ile önemli gelişmeler sağlanmıştır. Bu gelişme ile birlikte daha çok kişi bakım sigortasından yararlanmıştır kullanılır (Pflegetagegeldversicherung, t.y.).

Beş bakım derecesi, ilgili olumsuzluğun türünü ve ciddiyetini bedensel, ruhsal veya zihinsel olmasından bağımsız olarak bunun türünün ve ağırlı̆ııın tespit edilmesini sağlar. Bakım dereceleri ve böylelikle bakım sigortasının yardım kapsamı da bakıma muhtaç kişinin bağımsızlığına ve becerilerine ilişkin olumsuzlukların ağırlığına dayanmaktadır. Bakım derecesi, bakım uzmanlığı ile gerekçelendirilen bir ekspertiz enstrümanı yardımıyla tespit edilmektedir. Beş bakım dereceleri bağımsızlığa veya becerilere ilişkin düşük kısıtlamalardan (Bakım derecesi 1) bakımla ilgili ihtiyaç karşılamaya ilişkin özel gereksinimler ile bağdaşan bağımsızlığa veya becerilere ilişkin en ağır kısıtlamalara (Bakım derecesi 5) kadar kademelendirilmiştir. Bakıma ilişkin ihtiyaçların sağlanması konusunda olağanüstü derecede yardım ihtiyacına sahip olan bakıma muhtaç kişiler, 
bakım uzmanlığına ilişkin nedenlerden dolayı gerekli olan toplam puan sayısına ulaşılmadığında dahi bakıma muhtaçlık derecesi 5'e atanabilirler. Bakım kasalarının federal üst birliği, bakım uzmanlığı açısından bu tür özel ihtiyaç durumlarında gerekçelendirilen şartları, ekspertiz direktiflerinde belirlemektedir (Yakınların Bakımı, 2020).

Bakıma muhtaç kişinin hangi bakım grubuna alınacağına Bakım Sigortası karar vermektedir ve bakım gereksinimi de bakım kasasından karşılanmaktadır. Bakım kasaları, kapsamındaki sigortalılara yönelik bakım hizmetlerinden sorumludurlar. Bu kasalar, sigortalıların kişisel sorumlulukları konusunda kendilerini bilgilendirmekle ve onları sağlıklı ve bakıma muhtaçlık halini önleyici bir yaşam tarzı hakkında uyararak desteklemekle ve sağlığını koruyucu önlemlere katılımlarını teşvik etmekle yükümlüdür (Metin, 2014, s. 4). Yapılan istek doğrultusunda bakım kasası, bakıma muhtaç kişinin istediği bakım hizmetini teyit ettirmek üzere MDK'yı görevlendirmektedir. MDK, Almanya'da bakım uygulamalarını denetleyen kuruluştur. Almanya'da uzun süreli yaşlı bakım hizmetlerinin kalite güvencesinden ve bakım ihtiyaçlarının değerlendirilmesinden MDK sorumludur (European Commission, 2017, s. 6; Özmete ve Hussein, 2017, s. 20). MDK’nın görevlendirdiği bilirkişi de bakıma muhtaç kişi ile görüşerek ihtiyaçlarını bakım sigortası kademeleri çerçevesinde inceleyerek bakım kasasına sunmaktadır. Bakım kasası da bu rapora istinaden yaşlının isteklerinin karşılanıp karşılanmayacağına ya da karşılanacak ise bunların nasıl karşılanacağına karar verip yaşlıyı bilgilendirmektedir (European Commission, 2017, s. 6).

Bakım kasasının bakıma muhtaç kişinin bakımına yönelik olarak ayırdığı parasal kaynak miktarı ve hizmetlerin düzeyi kademelere göre değişiklik göstermektedir (Çağlar, 2015, s. 98).

\section{Bakım Sigortasından Sağlanan Yardımlar ve Yararlanma Koşulları Bakım sigortasından sağlanan yardımlar}

Almanya'da bakım sigortası, bakıma ilişkin tüm masrafları karşılamamaktadır. Bütün hizmetler yerine bir tavan belirlenmiş ve temel bakım ihtiyaçları kapsama alınmıştır (Ayhan, 2014, s. 85). Almanya'da sigorta kapsamına alınan kişilere sosyal güvenceleri ve gelir durumları esas alınarak ayni ve nakdi yardımlar yapılmaktadır (Ağören, 2017, s. 16). Diğer bir ifadeyle, bakıma muhtaç durumda olan birey, bakım hizmeti alabileceği gibi, bunun yerine yalnızca bakım parası talep etme hakkı da bulunmaktadır. Bakım sigortasından sağlanan parasal yardım, bakıcıya değil bakıma muhtaç kişiye verilmektedir. Bakım hizmetleri ise "evde bakım" ve "kurumsal bakım" olmak üzere iki şekilde sunulmaktadır (Balcı-Gökçeoğlu, 2017, s. 65). Aynı zamanda bakıma muhtaç kişiye yapılan yardımlar, kişinin bakım ihtiyacına ve bakımın evde veya bakım merkezlerinde gerçekleşmesine göre değişmektedir (Ağören, 2009, s. 21; Çağlar, 2015, s. 95). Alman sosyal yardım hukukuna göre sosyal bakım, sosyal yardımlara göre daha ön planda yer almaktadır. Sağlanan sosyal hizmetler, muhtaç durumdaki hak sahibinin özel gereksinimleri, istekleri ve becerilerine göre sunulmaktadır. Sosyal yardım ise daha çok "son çare" olarak uygulanmakta ve sadece başvuru yapmak yeterli olmamaktadır (Cengiz, 2018, s. 28). Bakım ihtiyacı içinde olan kişiler ve yakınları için de danışmanlık ve aynı zamanda eğitim kursları da sunulmaktadır. Yardımlar kanunlarla belirlenmektedir (Ökem ve Can, 2014, s. 16).

\section{Evde bakım}

Dünya Sağlık Örgütü (World Health Organization - WHO) tarafından yapılan tanıma göre evde bakım hizmetleri, "bireyin sağlı̆̆ını korumak, yükseltmek, yeniden sağllğına kavuşturmak amacıyla sağlık ve sosyal hizmetlerin profesyonel düzeyde veya aile bireyleri tarafindan, bireyin kendi evinde veya yaşadiğ ortamda sunulmasidır" (WHO, 2008, s. 1). 
Almanya'da bakım sigortasından sağlanan yardımlarla ilgili olarak, bakıma muhtaç kişilere bakım hizmetlerinin evde sunulması düzenlenmiştir. Evlerinde sunulan bu bakım hizmetine Gezici Bakım Hizmetleri de denilmektedir. Evde bakım hizmetleri, bakıma muhtaç engelli ve yaşlı bireye ve ona bakan ailesine verilen her türlü desteği kapsamaktadır. Kurumsal bakıma alternatif olan evde bakımda, bakım ihtiyacı içinde olan kimselere ve onlara bakım hizmeti veren aile üyeleri veya profesyonel bakıcılara destek olmak amacıyla, kamusal ya da özel kuruluşlar tarafından evde verilen sağlık ve sosyal bakım hizmetleridir. Diğer bir ifadeyle evde bakım hizmetleri, aile fertleri veya yakınlar tarafından ya da her ikisi tarafindan birlikte yerine getirilmektedir (Balc1-Gökçeoğlu, 2017, s. 55-65).

Bakım sigortasının sunduğu hizmetler aracılığıyla öncelikli olarak evde bakım uygulaması ile akraba ve komşular tarafından sağlanacak bakımın desteklemesi hedeflenmektedir. Sigortalılarında sağlıklı bir yaşam tarzını benimseyerek, kendisine bakan kimselerin önerilerine uymaları gerekmektedir (Metin, 2014, s. 4).

Evde bakım hizmetlerinde temel amaç, bakıma ihtiyaç duyan yaşlllara uygun ve yüksek kaliteli sağlık hizmetleri ve sosyal hizmetleri sağlayarak, resmi ve gayri resmi bakıcılar tarafından uygun olduğunda teknoloji kullanımıyla yaşadıkları çevrede bakım hizmeti alabilmelerinin sağlanabilmesidir (WHO, 2008, s. 1). Bu sayede de yaşlının bir bakımevine gitme zorunluluğu ortadan kalkmakta ya da ertelenmiş olmaktadır (Çağlar, 2015, s. 105). Evde bakım hizmeti muhtaç bireyin ihtiyaçlarını en iyi şekilde karşılayarak aileye destek vermeyi ve muhtaç bireylerin kendi evlerinde olabildiğince uzun, bağımsız, rahat ve huzurlu bir şekilde yaşamalarının sağlanmasını hedeflemektedir. Kurumsal bakımın olabildiğince geciktirilmesinin sağlanması da evde bakımın hedefleri arasında yer almaktadır (Aile ve Sosyal Politikalar Bakanlığı Özürlü ve Yaşlı Hizmetleri Genel Müdürlüğ̈̈, 2013, s. 4). Bu nedenle de öncelikle evde bakım koşullarının iyileştirilmesi ve aile bireylerine destek olmak için gerekli tedbirlerin alınması gerekmektedir.

Evde bakımdan yararlananlar, ayni veya nakdi bakım yardım almaktadır. Bakıma muhtaç kişi ailesinden birisinin bu hizmetleri vermesi için doğrudan nakit yardım talep edebilir. Bu durumda verilen bakım hizmetleri genellikle gönüllülük esasına dayanmaktadır. Bu durumda eğer bakım hizmeti, sigortalının aile bireyleri, yakınları veya profesyonel anlamda bakıcılık hizmeti sağlamayan bir kişi tarafından gerçekleştirilirse, bakıma muhtaç durumda olan kişiye, bakım parası adı altında nakdi bir yardım da sunulmaktadır (Hekimler, 2015, s. 65). Nakit yardımlar, doğrudan bakıma muhtaç kişiye verilmektedir. Bakımın garantilenmesi şartıyla kişi parayı kendisine bakan akrabasına veya gayri resmi bir bakıcıya aktarabilmektedir (Ökem ve Can, 2014, s. 16). Bu yardımı alanlar bakım kalitesinin geliştirilmesi amacıyla profesyonel bir bakıcıyla yılda iki kere inceleme amaçlı temas kurmalıdır. Bakım hizmetinin profesyonel bir kişiden alınması durumunda bakıma muhtaç kişiye bakım sigortasından ödenen bakım parası kendisine değil, doğrudan bakım hizmetini yerine getiren profesyonel kişiye ödenmektedir. Almanya'da yaşlı bakımı alanında çalışan profesyonellerin iş yüklerinin fazla olmasına rağmen oldukça düşük ücretlerle çalıştırılması söz konusudur (Danış ve Genç, 2011, s. 181).

Alman sisteminde bakıma muhtaç kişilere evde bakım hizmeti kapsamında aşağıdaki hizmetler sunulmaktadır (Metin, 2014, s. 29):
i. Beden temizliği,
ii. Yemek yeme,
iii. Mobilite,
iv. Evle ilgili işler,
v. Tibbi yardım,
vi. Sosyal bakım. 
Almanya' da bakım hizmetinin aile üyelerinden birisi tarafından yerine getirilmesi sırasında onun hastalanması durumunda veya kendisinin de dinlenme ihtiyacının olabileceği düşüncesiyle bu konuda bir alternatif geliştirilmiştir. Böyle bir durum ortaya çıktığında, bakım ihtiyacı duyan kişi bir yıl içerisinde toplam bir aylık süre için yedek bakım adı verilen geçici bir bakım hizmetinden yararlanmaktadır. Bu geçici bakım da bakıma ihtiyacı duyan kişinin yakını veya profesyonel bir kişi tarafından sağlanmaktadır (Hekimler, 2015, s. 66).

Almanya'da bakıma muhtaç kişinin daha iyi bakım hizmeti alabilmesi için evinde tadilat yapılması gerekliyse bu da bakım sigortasından karşılanmaktadır. Bakım kasası, bakım dereceleri 1 ila 5 arası bakıma muhtaçlara dilekçe üzerine, evde bakımı mümkün kılan, kolaylaştıran veya bakıma muhtaç kişilerin bağımsız bir hayat sürdürebilmeleri için 4.000 Euro'ya kadar bir sübvansiyon ödemektedir. Bu tür önlemlerin amacı ayrıca, bakım elemanının yapabileceğinden fazlasını yapmasını önlemektir belirlemektedir (Yakınların Bakımı, 2020).

Bütün bunlara ilave olarak evde bakımı teşvik etmek amacıyla bakımı yapan kişiler için de belirli şartlar altında emeklilik ve işsizlik sigortası primlerinin ödenmesi gibi sosyal güvence uygulamaları başlatılmıştır. Bu sırada primlerin miktarı da bakım kademesine ve seçilen hizmete göre belirlenmektedir. Bakımı birden fazla kişi birlikte üstendiğinde ise primler orantılı olarak ödenmektedir. Bu kişiler aynı zamanda prim ödemeksizin kaza sigortasından da yararlanabilmektedirler (Şuözer, 2017).

Bakım parasını alma şartı, evde bakımın kendilerince sağlanmasıdır. Örneğin yakınlar veya diğer gönüllü çalışan bakıcılar tarafından, en az bakım derecesi II de evde bakımın kendilerince sağlanması şarttır. Bakım parası, bakıma muhtaç kişiye bakım kasası tarafından havale ile gönderilmektedir. Onlar, bu bakım parasını istedikleri gibi kullanabilirler ve genelde bakım parasını kendisine bakan kişilere takdir olarak vermektedirler. Bakım parası ayrıca ayakta maddi bakım yardımları ile kombine edilebilir (Yakınların Bakımı, 2020).

Ayni yardımlar kapsamında, bakım ihtiyacı olan kişilere ve yakınlarına danışmanlık hizmetleri sunulmaktadır. Nakdi ve ayni yardımların birleştirilmesi de mümkündür (Metin, 2014, s. 31; Taş̧̧ı, 2010, s. 190).

\section{Evde Bakım Yardımı Tutarları}

Bu yardımın miktarı ve kapsamı bakıma muhtaç sigortalının hangi bakım sınıfına girdiğine bağlıdır. Bakıma muhtaç sigortalıya bakım parası ödenmektedir.

- Bakım Parası; Bakıma muhtaç sigortalının bakımı aile üyelerinden birisi veya komşularından biri tarafından yapılırsa Bakım Sigortası Kasası, bakım sınıfına göre belirlenmiş olan bakım parasını ödemekte ve de ayrıca bakımı yapan kişinin emeklilik sigortası aidatlarını da karşılamaktadır. 2017 yılından beri bakıma muhtaçlık derecelerine bağlı olarak aylık yardımlar Bakım Seviyesi II için 316 Euro, Bakım Seviyesi III için 545 Euro, Bakım Seviyesi IV için 728 Euro, Bakım Seviyesi V için 901 Euro olarak ödenmektedir. Bakıma muhtaçlık derecesi I için sadece aylık 125,00 Euro'ya kadar destek tutarı verilir (Yakınların Bakımı, 2020).

Profesyonel olmayan bakıcı belirli bir süre hizmet veremezse, bakıma muhtaç olan kişiye bakım sigortası tarafından telafi edici yardımlar yapılmaktadır. Özel bakıcının tatilde olması veya hastalıktan dolayı mazeretli olması durumunda, bakım sigortası II ila $\mathrm{V}$ arası bakım derecelerindeki bakıma muhtaçlar için her bir takvim yılında en fazla altı haftaya kadar yedek bakımın belgelenmiş masraflarını karşılar. Bu bakım da ayakta bakım hizmeti, münferit bakım elemanları, gönüllü bakıcılar ve ayrıca akrabalar tarafından gerçekleşebilir (Yakınların Bakımı, 2020). 
- $\quad$-Bakım Hizmeti Yardımı; Bakıma muhtaç sigortalının günlük bakımı aile üyelerinden birisi veya komşuları tarafından yapılamıyor veya bakımı üstlenecek başka bir kişi de bulunamıyorsa Bakım Sigortası Kasası, sigortalıya Bakım Hizmeti Yardımı sunulmasını sağlar ve bu hizmetin karşılığı olarak Bakım Servisine bakım gruplarına göre belirlenmiş olan bakım yardım parası ödenir (Yakınların Bakımı, 2020).

\section{Kurumsal Bakım}

Kurumsal bakım, günlük bakım ihtiyacını karşılamada zorluk çeken ya da sağlık sorunu veya engeli nedeniyle bakım ihtiyacı içinde olan kimselere kamusal veya özel kurumlar bünyesinde yatılı veya gündüzlü olarak verilen sağlık ve sosyal bakım hizmetleridir (Balcı-Gökçeoğlu, 2017, s. 54). Sigortalının bakımını, kendi seçeceği bir bakım servisine yaptırma hakkı bulunmaktadır (Özmete ve Hussein, 2017, s. 19).

\section{Kısmi yatılı gündüz ve gece bakımı}

Bakıma muhtaç sigortalının evde yapılan bakımının yeterli olmaması veya evde bakım hizmetinin tamamlanması için gerekli olması durumunda sigortalı, kısmi yatılı gündüz ve gece bakımı hakkından yararlanabilmektedir. Yarı sabit bakım hizmeti adı verilen bu bakımda yaşamını evinde idame ettiren ve bakım gereksinimi içinde bulunan bir kişinin gündüz ya da gece bakım hizmeti alması ifade edilmektedir (Çağlar, 2015, s. 110). Bu kapsamda verilen gece bakım hizmeti yatılı bir bakım kuruluşunda gerçekleştirilmektedir. Kısmi yatılı bakım hizmetleri, bakıma muhtaç kişinin evinden gündüz veya gece bakımı için kuruma gidiş ve dönüş naklini de içermektedir (Metin, 2014, s. 37).

Evde bakım hizmeti alan bir yaşlının yarı sabit bakım hizmetinden yararlanabilmesi için belirli koşulları taşıması gerekmektedir. Bu koşullardan ilki, evinde bakım hizmeti alan yaşlının bakım ihtiyacının yeterli düzeyde karşılanamaması, ikincisi ise yarı sabit bakım hizmetinin evde bakım hizmetini tamamlayıcı bir unsur olması durumudur. Yarı sabit bakım hizmetlerinden yararlanabilmek için aynı zamanda yaşlıyla ilgilenecek bir yakınının çalışıyor olması şartı da bulunmaktadır. (Ağören, 2009, s. 23).

\section{Tam yatılı bakım}

Evde veya kısmi yatılı bakımı mümkün olamayan bir sigortalı bakım yurduna yatırılmaktadır. Bu tür bakıma sabit bakım hizmetleri denilmektedir. Yatılı bakım kuruluşlarında kalan yaşlının bakım gereksinmelerinin karşılanması sabit bakım hizmetlerinin temel işlevidir. Tam yatılı bakım hizmeti sunulan kurumlarda, bakıma muhtaç kişilerin bakım kasaları tarafından bakım masrafları, sosyal danışmanlık masrafları ve bakım müessesinde oluşan tıbbi tedavi masrafları karşılanır (Metin, 2014, s. 36).

Sabit bakım hizmetleri; "sürekli bakım" ve "kısa süreli bakım" olmak üzere iki şekilde karşımıza çıkmaktadır. Sürekli bakım hizmetleri; sürekli bakıma ihtiyaç duyan yaşlılar için oluşturulmuş bir bakım hizmetidir. Kısa süreli bakım hizmeti ise, ameliyat, rehabilitasyon ya da kişinin sağlığını negatif yönde etkileyen durumlar nedeniyle geçici bir süre yatılı bakım kuruluşunda bakım hizmeti almak durumunda kalanlar için geliştirilmiş bir bakım hizmetidir. Yaşlıya bakım hizmeti veren kişinin hasta olması veya tatile gitmesi durumunda da yaşlı, kısa süreli bakım hizmetinden yararlanabilmekte ve yedek bir bakıcının da masrafları karşılanmaktadır. Ancak yedek bakıcı sadece evde bakımından altı ay yararlandıktan sonra tutulabilir. Yaşlı yılda bir kez olmak üzere dört haftalık süreyle yaşlı bakım evi, rehabilitasyon merkezleri ve yaşlılar evi gibi kuruluşlarda ikamet edebilme hakkına sahiptir (Çağlar, 2015, s. 101).

Bakım sigortasının kısa süreli bakıma ilişkin yardımı, tutar açısından bakım derecelerinde farklılık göstermemektedir. Yardımın tutarı takvim yılı başı sekiz haftaya kadar 1.612 Euro'ya kadardır. Bakım derecesi 
I'e sahip bakıma muhtaçlar ayda 125 Euro tutarındaki yük azaltma tutarını, kısa süreli bakımın yardımlarını alabilmek için kullanabilirler (Yakınların Bakımı, 2020).

Yeni bakıma muhtaçlık kelimesinin 1 Ocak 2017 tarihli bakım sigortası yasasına dâhil edilmesinden bu yana bakım derecesi I'e düşük bağımsızlık veya beceri kısıtlaması olan insanlar kademelendirilmektedir. Bu çoğu zaman örneğin omurilik veya eklem rahatsızlıklarından dolayı düşük bedensel kısıtlaması olan insanlar için geçerlidir. Bu kişiler için daha az kısıtlamalarda bile bakıma muhtaç kişilerin ve bakım elemanlarının desteğine, gözetimine ve eğitimine ilişkin yardımlar sunulmasından dolayı bağımsızlığa ulaşmak veya bağımsızlığı iyileştirmek için her zamankinden daha erken bir zamanda olanaklar oluşturulmaktadır. Bakım derecesi I yürürlüğe koyulduktan sonra bakım sigortası yardımı alabilen insanların çevresi son derece artmıştır (Yakınların Bakımı, 2020).

\section{Diğer yardımlar}

Bakım yapan yakınlar tıbbi rehabilitasyon yardımlarına daha kolay erişebilir. Bakıma muhtaç kişi aynı zamanda rehabilitasyon kurumunda gözetim altında olabildiği durumlarda bakım sigortası kasaları masrafları üstlenir. Aksi takdirde gözetimi sağlık ve bakım kasaları organize etmelidir. Bakım kasaları ve bakım noktaları ayrıca yakınlara ilgili şekilde danışmanlık hizmetleri sunmalıdır ve diğerlerinin yanı sıra yük azaltma imkânları hakkında bilgi vermelidir (örneğin bakımı yapanların yüklerinin azaltılmasına ilişkin seçenekler, tedbir ve rehabilitasyon seçenekleri) (Yakınların Bakımı, 2020). Danışmanlık hizmetleri kapsamında evde bakım hizmetlerindeki kalitenin korunması ve bakımı üstlenen kişilere uzman desteği verilmesi amaçlanmaktadır (Metin, 2014, s. 31).

Bakıma muhtaç kişi, teknik bakım yardımcılarının masrafları için en fazla 25 Euro olmak üzere yüzde on oranında katkıda bulunmak zorundadır. Daha büyük teknik bakım yardımcı malzemeleri genellikle ödünç verilmektedir ve böylece bu katkıya gerek kalmamaktadır. Tüketim ürünlerinin maliyetleri için bakım kasası tarafından ayda 40 Euro'ya kadar ödeme yapılmaktadır. Tekerlekli sandalyeler veya yürüteçler için bir hekim tarafından reçete yazıldıysa, bunların masraflarını bakım kasaları karşılamaktadır (Yakınların Bakımı, 2020).

\section{Bakım sigortasından yararlanma koşulları}

Yukarıda da ifade ettiğimiz üzere bakım sigortasından yararlanmanın ilk koşulu bakıma muhtaç olmaktır. Bakıma muhtaçlık kavramına yukarıda değindiğimizden burada tekrar ele almayacağız.

Bakım sigortasından yararlanabilmenin diğer bir koşulu son 10 yılda en az 5 yıl sigortalı olarak prim ödemiş olmaktır. Yoksul olan ve işsiz durumda bulunanların bakım sigortası primi devlet tarafından karşılanmaktadır.

Bakım sigortasından yararlanabilmenin son koşulu ise, aynı zamanda sigortalının bakım sigortasına da başvurması gerekmekte olup beden temizliği, beslenme, alışveriş vb. günlük temel aktivitelerinden en az ikisini minimum altı ay boyunca yapamaması gerekmektedir (Ağören, 2009, s. 18-19). Sigortalının bakıma muhtaç olup olmadığı, Bakım Sigortası Kasasına başvurması üzerine Hastalık Kasası (Krankenkasse) uzmanlarınca tespit edilir (Özmete ve Hussein, 2017, s. 19). Yapılan başvurundan sonra da sigorta kurumu tarafından en geç beş haftalık bir süre içerisinde başvuru ile ilgili yazılı bir kararın verilmesi gerekmektedir.

\section{Bakım sigortasının finansmanı}

Bakıma muhtaçlık riskinin ortaya çıkmasından kaynaklanan finansman sorunu en önemli sorun alanı olarak karşımıza çıkmaktadır. Almanya'da bakım hizmetlerinin finansmanında temelde primli sistem uygulanmaktadır. Diğer bir ifadeyle bakım sigortası da diğer sigorta türlerinde olduğu gibi katkı payı 
ödemelerinden finanse edilmektedir. Bu sistemde, işçi, işveren, emekli ve devlet memurlarının ücretlerinden belirli bir oranda prim kesilmektedir.

Almanya'da bakım sigortasının kamu ve özel olarak iki kısma ayrıldığına yukarıda değinmiştik. Kamu bakım sigortasının finansmanı işçi ve işverenlerden eşit oranlarda alınan primlerle sağlanmaktadır. Primler bakım sigortalısının kazancı üzerinden alınmaktadır. Başlangıçta \%1 olarak belirlenen oran 1 Temmuz 1996 tarihinde \%1,7’ye çıkartılmıştır. 1 Temmuz 2008 tarihinde ise oranda bir güncelleme yapılarak 1 Temmuz 2008 tarihinden itibaren sigortalı ve işveren tarafından eşit olarak brüt ücretin \%1,95 oranı üzerinden prim kesilmeye başlanmıştır. 2005 yılında yasada yapılan değişiklikle, çocuğu olmayanların ilave olarak \%0,25 prim ödemesi öngörülmüştür. Bu değişiklik, çocuğu olmayan sigortalıların, sigortadan sağlanan yardımlara daha fazla ihtiyaç duyacağı düşüncesine dayanmaktadır. Emeklilerin primi ise emekli fonlarından sağlanmaktadır (Caniklioğlu ve Ünal, 2011, s. 2272; European Commission, 2017, s. 5).

Bakım sigortasının 2013 yılı itibariyle belirlenen prim miktarı ise katılımcının brüt gelirinin \%2,05 olarak belirlenmiştir. Bu oran işveren ve çalışan arasında yarı yarıya paylaşılmaktadır.

Bakım sigortası primi 2015 yılı itibariyle \%2,35’e çıarılmış ve çocuğu olmayan kişilerin prim miktarı \%2,6 olarak belirlenmiştir (Çağlar, 2015, s. 94). 1 Ocak 2017 tarihinden itibaren bakım sigortası ödenecek katkı payı \%2,55 olarak tespit edilmiştir (Hekimler, 2017, s. 237; Ağören, 2017, s.16; European Commission, 2017, s. 5). Oysa 2020 tarihi itibariye zorunlu bakım sigortasının prim tutarı çocuklu sigortalılar için \%3,05, çocuksuz sigortalılar için \%3,30 olarak belirlenmiştir (Bundesministreium für Gesundheith, 2020).

Emekli maaşı alanlarda bakım sigortası kapsamına alınmışlardır. Emeklilerden de bakım sigortası için prim alınmaktadır. Emekliler primin tamamını kendileri ödemekle yükümlü kılınmışlardır. Bu uygulamaya ek olarak 1 Ocak 2005 tarihinden itibaren 1940 yılı ve sonrasında dünyaya gelenler ve 23 yaşını doldurmuş çocuğu olmayan katılımcılar geçerli olan katkı payı ödemesine $\% 0,25$ 'lik ek bir katkı payı sunmakla yükümlü kılınmıştır (Yakınların Bakımı, 2020).

Emekli olduktan sonra sürekli ikametgâhını Almanya dışında bir Avrupa Birliği üyesi ülkeye veya İzlanda, Lichtenstein, Norveç'e taşıyan bir kişi için, taşınılan ülke ile Almanya arasında bir sosyal güvenlik anlaşması var ise, Alman mevzuatı aynı şekilde uygulanmaya devam edilmektedir. Fakat emekli olup Türkiye'ye kesin dönüş yapan Türk vatandaşları, Almanya ile Türkiye arasında bağıtlanmış olan sosyal güvenlik anlaşmasında bakım sigortasına ilişkin bir düzenlemeye yer verilmesi sebebiyle, farklı bir uygulama bulunmaktadır. Buna göre emekli olup daimi ikametgâhını Türkiye'ye taşımış olan emeklilerin, ikametgâhın taşınması ile birlikte, sağlık sigortası güvencesi yanında bakım sigortası güvencesi de ortadan kalkacağından emekli aylıklarından bakım sigortasına herhangi bir prim kesintisi yapılmamaktadır. (Hekimler, 2017, s. 238).

Devlet de yoksul olan ve işsiz durumda bulunanlar adına prim ödeyerek katkıda bulunmaktadır. Sigortalının bağımlıları ayrıca prim ödemeden bakım sigortası kapsamına alınmaktadır (Ağören, 2009, s. 18; Çağlar, 2015, s. 93; European Commission, 2017, s. 6).

2013 yılında yürürlüğe giren Yeni Bakım Kanunu'na göre devlet bakım sigortası ödemelerinde ayda 5 Euro, yılda toplam olarak 60 Euro olmak üzere bakım sigortası kapsamında olan herkesin devletçe desteklenmesi öngörülmüştür. Bu desteklemeye özel bakım sigortasında yer alanlar da dâhil edilmiştir (Çağlar, 2015, s. 94). 1 Ocak 2017 tarihi itibariyle ikinci Bakımı Güçlendirme Yasası ile özellikle esaslı ve yeni bir bakıma muhtaçlık terimi yürürlüğe girmiştir. Eski bilinen üç bakım kademesinin yerini artık yeni yardım tutarlarına sahip beş yeni bakım derecesi almıştır. Günümüze kadar bakıma muhtaçlık bedensel kaynaklı kısıtlamalara dayanırken, 
artık ayrıca ruhsal ve psikolojik kaynaklı kısıtlamalar da aynı derecede dikkate alınmaktadır(Yakınların Bakımı, 2020).

Alman Hukukunda bakım sigortası, sosyal sigorta tekniğine uygun olarak düzenlenmiş olup, sağlık sigortasının içinde yer almaktadır. Hastalık Kasaları bünyesinde bakım sigortasından sağlanan yardımları yerine getirmek için Bakım Kasaları oluşturulmuştur. Sağlık sigortasının kapsamında olan zorunlu ya da isteğe bağlı tüm sigortalılar ile aile bireyleri aynı zamanda bakım sigortasının da kapsamındadırlar. Ancak isteğe bağlı sigortalı olanlar, kendileri ve aile bireylerinin bakım sigortası bakımından özel sigortanın kapsamında olduklarını ve aynı değerde bir sigorta korumasına sahip olduklarını ispatlarlarsa bu sigortanın kapsamı dışında kalabilmektedirler (Caniklioğlu ve Ünal, 2011, s. 2271-2272).

Kanunun beşinci bölümünde bakım sigortasının organizasyon yapısı belirlenmektedir (Hekimler, 2017, s. 238). Almanya'da bakım sigortasının yanında yoksul bireyler için gelir testine dayalı sosyal yardım programları da uygulanmaktadır. Dolayısıyla bakım sigortası büyük oranda sigorta sistemi (primler) ile finanse edilmekle birlikte Almanya'da bakım sigortasının finansmanında karma model uygulanmaktadır (Ayhan, 2014, s. 81).

\section{Türkiye'de Bakım Hizmetlerinin Kapsamı ve Sağlanan Yardımlar Türkiye'de Bakım Hizmetlerinin Genel Görünümü}

Türkiye'de yaşlılara yönelik sosyal politikalar incelendiğinde, yaşlılara bir gelir güvencesi sağlama ve ihtiyacı olanlara bakım hizmeti verilmesi şeklinde olduğu görülmektedir (Özmete ve Hussein, 2017, s. 32). Dünya'da yaşlı nüfus oranının giderek artması ve ortalama yaşam süresinin uzaması ile birlikte yaşlılara yönelik bakım politikalarının önemini arttırdığına yukarıda değinmiştik. Demografik geçiş sürecinde yaşanan dönüşümle birlikte, Avrupa Birliği ülkelerinde uygulanan bakım hizmetleri Türkiye için de önemli hale gelmiştir.

Türkiye genç nüfus yapısına sahip olmakla birlikte nüfusu yaşlanma eğilimine girmiştir. Türkiye'nin nüfusu son zamanlarda giderek azalma eğilimi göstermektedir. 2017 yılı itibariyle 80 milyon 810 bin 525 olan nüfusumuzun (TÜIK, 2018a), 2050 yılında 85 milyon civarında olacağı ve bu tarihten sonra azalmaya başlayacağı tahmin edilmektedir. Ülkemizde nüfus projeksiyonlarına göre, genç nüfus oranının, 2040 yılında $\% 13,4,2060$ yılında \%11,8 ve 2080 yılında ise \%11,1 olacağı (TÜİK, 2020b); yaşlı nüfus oranının ise 2040 yılında \%16,3, 2060 yılında \%22,6 ve 2080 yılında ise \%25,6 olacağı beklenmektedir (TÜİ, 2020a). Bu azalma, bugün Avrupa'nın yaşadığı önemli sorunlardan biri olan yaşlı nüfus probleminin ilerleyen yıllarda Türkiye'de de yaşanacağını göstermektedir. Ortalama yaşam süresinin uzaması beraberinde kaliteli ve insana yakışır bir hayatın idame edilmesini getirmemektedir. Değişen aile yapısıyla beraber yeni sosyal risklerin (özellikle tek ebeveynli aileler, ortalama ömrün uzaması, yaşı nüfusun artması vb.) ortaya çıkması ve bu risklere maruz kalma olasılığının artması, yeni önlemlerin alınmasını ve sosyal devletin bu sorunlara çözümler sunmasını gerektirmektedir (Cengiz, 2018, s. 26). Ortaya çıkan bu risklerin başında da bakıma muhtaçlık riski gelmektedir. Bu risk ile karşılaşan ve karşılaşacak olanlar için gerekli yardım ve tedbirlerin sağlanması, sosyal devlet olmanın bir gerekliliğidir. Son yıllarda Türkiye'de aile yapısında büyük bir değişim ortaya çıkmış, aynı çatı altında iki hatta üç neslin birlikte yaşadığı aile yapıları çözülme sürecine girmiş ve bu kapsamda çekirdek aile yapısına dönüş başlamıştır. Kentlerde baskın olan çekirdek aile yapısı artık kırsal alanda da görülmeye başlamıştır. Bunun doğal sonucu da özellikle çocuk, engelli ve yaşlıların ihtiyaç duydukları bakım ve gözetimden mahrum kalmalarıdır. Ailenin etkinliğinin giderek azaldığı bu alanda başka kurumlar bu boşluğu doldurmaya başlamıştır (Cengiz, 2018, s. 26). Türkiye'de sosyal, kültürel ve ekonomik açıdan yaşanan dönüşümle beraber bakımda birincil sorumlu olarak görülen kadınların çalışma yaşamında daha çok yer almaya başlaması da bakımda ailenin rolünü giderek zayıflatmaktadır. Türkiye'de hem yaşlı, hem de engelliye 
yönelik bakım hizmetleri, kayıt dışı olarak yürütülmektedir. Kayıt dışılığın ulaştı̆̆ı boyut, ülkemizde yasa dışı bulunan ve çalışma izni bulunmayan yabancılar tarafından da bu hizmetin verildiği düşünüldügünde daha da artmaktadır. Nitekim Devletin yaşlılara yönelik sosyal politikalar üretmesinin gerekliliği de 1982 Anayasasında düzenleme altına alınmıştır. Anayasanın 41. maddesinde, "Aile, Türk toplumunun temelidir ve eşler arasında eşitliğe dayanır. Devlet, ailenin huzur ve refahı ile özellikle ananın ve çocukların korunması ve aile planlamasının öğretimi ile uygulanmasını sağlamak için gerekli tedbirleri alır, teşkilatı kurar” hükmü yer almaktadır. Anayasanın "Kanun Önünde Eşitlik" ile ilgili 10. maddesinin ek fikrasında; “Çocuklar, yaşlılar, engelliler, harp ve vazife şehitlerinin dul ve yetimleri ile malul ve gaziler için alınacak tedbirler eşitlik ilkesine aykırı sayılmaz" ifadesi yer almaktadır. Yine Anayasanın 60. maddesinde, "Herkes sosyal güvenlik hakkına sahiptir. Devlet bu güvenliği sağlayacak gerekli tedbirleri alır ve teşkilatı kurar" denilerek bütün vatandaşların sosyal güvenlik kapsamı altına alınması sosyal devlet anlayışı ile devletin yükümlülükleri arasına alınmıştır. Bu bağlamda yaşlılar da sosyal güvenlik hakkına sahiptir. 61. maddesinde ise, "Devlet, harp ve vazife şehitlerinin dul ve yetimleriyle, malul ve gazileri korur ve toplumda kendilerine yaraşır bir hayat seviyesi sağlar. Devlet engellilerin korunmalarını ve toplum hayatına intibaklarını sağlayıcı tedbirleri alır. Yaşlılar Devletçe korunur. Yaşllara Devlet yardımı ve sağlanacak diğer haklar ve kolaylıklar kanunla düzenlenir. Devlet, korunmaya muhtaç çocukların topluma kazandırılması için her türlü tedbiri alır. Bu amaçlarla gerekli teşkilat ve tesisleri kurar veya kurdurur" ifadeleriyle dezavantajlı gruplara yönelik yükümlülüklerini ayrıntılı olarak belirtmiştir. Bu maddeden de anlaşılacağı üzere yaşlıların karşılaştıkları sosyal sorunlara çözüm bulmak ve onlara yönelik sosyal yardım ve hizmetleri de ulaştırmak devletin sorumlulukları arasında yer almaktadır (Cengiz, 2018, s. $32)$.

Türkiye'nin sosyal ve aile yapısı nedeniyle, bakıma muhtaç kişiler ve yaşlılar genellikle aile üyeleri tarafından bakılmaktadır. Ev ve aile ortamında bakımın tercih edilmesi sosyal güvenlik sistemine de daha az mali külfet yüklemektedir. Ancak, bakımı sağlayan aile bireylerinin yükünü azaltmak, sosyal ve çalışma yaşamlarını sağlıklı bir şekilde sürdürebilmelerini sağlamak amacıyla planlanan sistem ile desteklenmeleri, en az muhtaç kişilerin bakımı kadar gereklidir (Ökem ve Can, 2014, s. 8).

Türkiye'de yukarıda bahsettiğimiz toplumsal yapıda meydana gelen bu değişmeler, yaşlıların geleneksel aile ve akrabalık ilişkilerinin dışında, devlet desteğine ve profesyonel hizmetlere olan ihtiyacını artırarak bakım sigortasının kurulması gerekliliğini ortaya çıkarmıştır (Hekimler, 2015, s. 71-72).

Türkiye'de yaşlanan nüfusuna yönelik ulusal ve kapsayıcı düzeyde bakım politikalarının oluşturulmuş olduğunu söylemek zordur (Oğlak, 2014, s. 222-223). Türkiye açısından yaşlllık bugün için bir tehlike olarak algılanmasa da yakın gelecekte ciddi bir tehdit olacaktır. Bu nedenle, bakım sigortasının kurulması gelecek için alınan bir önlem niteliğindedir. Aile, Çalışma ve Sosyal Hizmetler Bakanlığı, Engelli ve Yaşlı Hizmetleri Genel Müdürlüğ̈̈nün, gelir durumuna bakılmaksızın herkesi kapsayan bakım sigortasının hayata geçirilmesi ile ilgili çalışmaları sürmektedir (Oğlak, 2014, s. 223). Başbakanlık Özürlüler İdaresi Başkanlığı’nın 2011-2013 Bakım Hizmetleri Stratejisi ve Eylem Planı'nda yer alan hedeflerden biri, bakım sigortasının tüm nüfusu kapsayacak şekilde sosyal sigorta sistemi içerisinde düzenlenmesidir. Bununla birlikte, 2011 yılının Mayıs ayında da Özürlüler İdaresi Başkanı tarafından bakım sigortasının üç yıl içinde uygulamaya geçeceği taahhüt edilmiştir (Caniklioğlu ve Ünal, 2011, s. 2268).

Ülkemizde sigorta kolları 16.06.2006 tarihli ve 26200 sayılı resmi gazetede yayınlanan 5510 sayılı Sosyal Sigortalar ve Genel Sağlık Sigortası Kanunu'nda (SSGSSK) düzenleme altına alınmıştır. Bu Kanuna göre sigorta kolları uzun vadeli (malullük, yaşlılık, ölüm) ve kısa vadeli (iş kazası ve meslek hastalığı, hastalık, analık) olmak üzere iki kısımda yer almaktadır. İşsizlik sigortası da kısa vadeli bir sigorta kolu olmasına rağmen 5510 sayılı Kanunda değil 08.09.1999 tarihli ve 23810 sayılı resmi gazetede yayınlanan 4447 sayılı İşsizlik Sigortası 
Kanunu'nda düzenleme altına alınmıştır. Ancak bakım sigortasına yönelik bir düzenleme henüz mevzuatımızda yapılmamıştır.

Türkiye'de de hem bu sosyal riske maruz kalan kişilere daha fazla yardımlar yapılabilmesi hem de bakıma muhtaçlığın sosyal güvenlik sistemi içinde yer alabilmesi için bakım sigortasının kurulması büyük önem arz etmektedir.

Türkiye için kurulması düşünülen bakım sigortasının sürdürülebilir olması için öncelikle bakım muhtaç kişi sayısının doğru tespit edilmesi gerekmektedir. Bu sayının doğru tespit edilmesi de bakıma muhtaçlık kavramının doğru tanımlanmasıyla ilişkilidir.

\section{Türkiye'de Bakım Hizmetlerinin Kapsamı}

\section{Bakıma muhtaçık}

Bireylerin içinde bulundukları toplumda sağlıklı, kaliteli ve başkalarına muhtaç olmadan uzun süre yaşayabilmeleri sosyal devlet olmanın bir gereğidir. Dolayısıyla engelli ve yaşlı bireylere yönelik bakım hizmetlerinin niteliğinin yükseltilerek bu kişilerin yaşam kalitelerinin de arttırılmasının sağlanması sosyal devlet ilkesi temelinde büyük önem taşımaktadır (Aile ve Sosyal Politikalar Bakanlığı Özürlü ve Yaşlı Hizmetleri Genel Müdürlüğü, 2013, s. 2).

Bakıma muhtaçlık, genellikle engellilik ve ileri yaşlılık durumundan kaynaklanan bir sosyal risktir. Bu riske maruz kalanlar kendilerine yetemeyip başkalarının desteğine ihtiyaç duymakladırlar. Fakat ülkemizde önemli bir sosyal risk olan bakıma muhtaçlık konusunda herkesi kapsayan, yaşamını da devam ettirecek hizmetleri içeren ve uluslararası ölçütleri de dikkate alan bir tanım bulunmamaktadır (Aile ve Sosyal Politikalar Bakanlığı Özürlü ve Yaşlı Hizmetleri Genel Müdürlüğü, 2013, s. 16).

Ülkemizde bu konuda yapılan çalışmalar incelendiğinde genel olarak bakıma muhtaçlığı; “kişinin, fiziki hareket edebilirliğinin engellenmesi veya akli-ruhi becerilerinin kısttlanması sonucunda gerek beden temizliği, gerekse beslenme ve diğer ihtiyaçları için ev idaresinde sürekli olarak bir bakıcının düzenli bakımına ihtiyaç duyma hali” şeklinde ele alındığını görmekteyiz. (Balcı-Gökçeoğlu, 2017, s. 43-44).

Yaşlılığa bağlı muhtaçlık, çeşitli işlevlerde ve bedeni güçte gerileme ile birlikte ortaya çıkmaktadır. Bu bağlamda bakıma muhtaç yaşılıar günlük yaşamın basit aktivitelerini yerine getirirken başkalarının yardımına ihtiyaç duymaktadır. Bakıma muhtaçlı̆g belirleyen temel unsur günlük yaşam aktiviteleridir. Bakıma gereksinim duyan birey, günlük hayatın gereklerini yerine getirmekte güçlüklerle karşlaşmakta ve bu durum gerek kendisini gerekse de aile üyelerini zorlamaktadır (Danış ve Solak, 2014, s. 59). Bu nedenle yaşlılar ya sürekli ya da belirli süre bakım hizmetine ihtiyaç duymaktadırlar. Dolayısıyla yaşlılar da tıpkı engelliler ve hastalar gibi "bakıma muhtaç" kategorisinde düşünülmektedir (Taşçı, 2010, s. 185).

Günlük yaşam aktivitelerini; “bir kişinin temel ihtiyaçlarını karşılamak için bir günün akışı içinde rutin olarak yaptı̆̆ı aktiviteler” olarak tanımlayabiliriz. Günlük yaşam aktiviteleri her insanın günlük olarak tekrarlamak zorunda kaldığı, gerçekleştiremediği durumlarda ise ciddi sorunlar yaşayabileceği aktivitelerdir (Ayhan, 2014, s. 9).

Her ne kadar bakım sigortası, Türk toplumunun yapısına uygun görünmese de demografik geçiş sürecinde yaşanan değişim profesyonel hizmetleri artık zorunlu hale getirmektedir. Bunun yanında bu hizmetler için çalışırken prim ödeme yoluyla finansman sisteminin kurulması hem bireyler hem de ülkenin ekonomik yapısı için zorunluluk arz etmektedir. 


\section{Bakıma muhtaç kişilere yapılan yardımlar ve yararlanma koşulları Bakıma muhtaçlara yapılan yardımlar Parasal yardımlar ve yararlanma koşulları}

Bakıma muhtaç kişilere ülkemizde yürürlükte bulunan 5510 sayılı Kanun hükümlerine göre gerek uzun vadeli sigorta kollarından gerekse de kısa vadeli sigorta kollarından yardımlar yapılmaktadır. İş kazası ve meslek hastalığı sonucu bakıma muhtaç hale gelenlere yukarıda da ifade ettiğimiz üzere sürekli iş göremezlik geliri ile malul olmaları durumunda da malullük sigortasından malullük aylığı verilmektedir (5510 sayılı SSGSSK m.19; m.26).

5510 sayılı Kanun çerçevesinde sigortalının anılan sigorta kolundan sürekli iş göremezlik gelirine hak kazanabilmesi için bakıma muhtaç olduğunu belgelemesi gerekmektedir. Nitekim 5510 sayılı Kanunun 9. maddesinin ilk fikrasına göre sigortalının iş kazası ve meslek hastalığı sigortasından sürekli iş göremezlik geliri alabilmesi için, "iş kazası veya meslek hastalı̆̆ sonucu oluşan hastalık veya özürler nedeniyle Sosyal Güvenlik Kurumu Başkanlığı'nca yetkilendirilen sağlık hizmeti sunucularının sağlık kurulları tarafından verilen raporlara istinaden meslekte kazanma gücünün en az \%10 oranında azalmış ve başka birisinin sürekli bakımına muhtaç olduğunun tespit edilmesi gerekmektedir" (m.9/f-1).

Sigortalının malullük aylığı alabilmesi için ise Kanunun 26. maddesine göre;

a) "Sosyal Güvenlik Kurumu'nca yetkilendirilen sağlık hizmeti sunucularının sağlık kurullarınca hazırlanacak raporları doğrultusunda 5510 sayılı Kanunun 4. maddesinin (a) ve (b) bentleri kapsamındaki sigortalılar için çalışma gücünün veya iş kazası veya meslek hastalığı sonucu meslekte kazanma gücünün en az \%60'ını, (c) bendi kapsamındaki sigortalılar için çalışma gücünün en az \%60’nı veya vazifesini yapamayacak şekilde meslekte kazanma gücünü kaybettiği Sosyal Güvenlik Kurumu Sağlık Kurulu'nca tespit edilmesi,

b) En az on yıldan beri sigortalı bulunup, toplam olarak 1800 gün veya başka birisinin sürekli bakımına muhtaç derecede malul olan sigortalılar için ise sigortalılık süresi aranmaksızın 1800 gün malullük, yaşl1lık ve ölüm sigortası priminin bildirilmesi,

c) Maluliyeti nedeniyle sigortalı olarak çalıştığı işten ayrıldıktan veya işyerini kapattıktan veya devrettikten sonra Kurumdan yazılı istekte bulunması” koşullarını taşıması gerekmektedir. Ancak vazife malullüğü ve iş kazası veya meslek hastalığı için herhangi bir gün şartı bulunmamaktadır (m.26).

Ayrıca 5510 sayılı Kanunun 4. maddesinin (c) bendi kapsamındaki sigortalılar için iş kazası ve meslek hastalığı sigorta kolu uygulanmamakta bunun yerine vazife malullüğü aylığı verilmekte ve bu aylık da malullük derecesi oranına göre arttırılmaktadır (5510 sayılı SSGSSK m.47).

Ayrıca bakıma muhtaç engelli ve yaşılıların kendi evlerinde yaşamasını sağlayacak, ancak yaşadıkları ekonomik yoksunluğu gidermek amacıyla faydalanabilecekleri bir hizmet türü de Aile, Çalışma ve Sosyal Hizmetler Bakanlığı tarafından verilen "Evde Bakım Ücreti" hizmetidir. Buna göre Bakanlık, aynı ev içerisinde 24 saat bakım hizmeti vermek kaydıyla bakıma muhtaç durumda olan kişilere bakanlara aylık net asgari ücret kadar ödeme yapmaktadır. Bu hizmet 23.10.2007 tarih ve 26679 sayılı Resmi Gazetede yayınlanan "Bakıma Muhtaç Özürlülerin Tespiti ve Bakım Hizmeti Esaslarının Belirlenmesine İlişkin Yönetmelikte Değişiklik Yapılmasına Dair Yönetmelik" esaslarına göre düzenlenmektedir. 2019 yılında 1.384 TL tutarındaki evde bakım desteği, 2020 yılında 1.460 TL’ye yükseltilmiştir. Evde bakım ücreti alabilmenin üç koşulu bulunmaktadır. Bunlar (Sabah Gazetesi, 2020):
i. Gelir kriterinin uygun olması,
ii. Bakıma muhtaçlık kriteri,
iii. Ağır engelli olduğunu belirten sağlık kurulu raporu. 
Ancak bu uygulamanın bakım sigortasıyla bir ilgisi bulunmamaktadır. Bakım sigortası çok daha farklı bir konudur. Bu farklılıklara bakacak olursak;

- Birinci farklılık; bakım sigortası kapsamında verilen hizmetler tümüyle kişinin ileride yaşlılık durumlarını düşünerek ödedikleri primler yoluyla finanse edilmektedir.

- İkinci farklılık ise bakım sigortasında sadece profesyonel bakım hizmeti verilmemekte aynı zamanda sosyal bütünleşme de sağlanmaktadır. Bu yolla da bireyin yaşlanması dolayısıyla toplumla ilişkisini kesmesi engellenmektedir (Yakınların Bakımı, 2020).

Bütün bunlara ilave olarak ülkemizde 03.05. 2013 tarihli ve 28636 sayılı resmi gazetede yayınlanan 6462 sayılı Kanun ve Kanun Hükmünde Kararnamelerde Yer Alan Engelli Bireylere Yönelik İbarelerin Değiştirilmesi Amacıyla Bazı Kanun Hükmünde Kararnamelerde Değişiklik Yapılmasına Dair Kanun ile yeniden gözden geçirilen ve yürürlüğe giren 07.07.2005 tarihli 25868 sayılı Engelliler Kanunu kapsamında, bakıma muhtaçlık tanımı yapılmış ve yaşlı ve kronik hastalar da bu sınıflandırma içinde yer almıştır.

Sosyal yardımlar ile bakıma muhtaç bireylerin güvence altına alınmasına ilişkin düzenlemelere 10.07.1976 tarihli ve 15642 sayılı resmi gazetede yayınlanan "2022 sayılı 65 Yaşını Doldurmuş, Muhtaç, Güçsüz ve Kimsesiz Türk Vatandaşlarına Aylık Bağlanması Hakkında Kanunda” yer verilmiştir. Bu Kanun ile yaşlılar bakımından sosyal yardım düzenlenmiş olmakla birlikte bu düzenlemeler bakıma muhtaçlık riski ile değil doğrudan yaşlılık olgusu ile ilişkilendirilmiştir. 65 yaşını doldurmuş kişiler diğer öngörülen koşulları da sağlamaları halinde bakıma muhtaç olmasalar bile bu Kanun kapsamında aylığa hak kazanabilmektedirler. Yaşlı maaşı alan kişi sayısı 2002 yılında 746.468 iken bu sayı 2019 yllı sonu itibariyle 805.432 olmuştur (Aile, Çalışma ve Sosyal Hizmetler Bakanlığ 1 2020, s. 99).

Kanunda, bakıma muhtaç yaşlılar bakımından ayrıca bir koruma sağlanmaması bir eksikliktir. Çünkü bakıma muhtaçlık yaşlılık olgusu dışında ilave harcamaları gerektirmektedir. 2022 sayılı Kanunda bakıma muhtaçlık riskini güvence altına alan düzenlemeler de bulunmaktadır. Ancak, bu konudaki düzenlemeler bakıma muhtaç herkesi değil, sadece belirli bir grubu kapsamına almaktadır. Bu koruma sadece bakıma muhtaç engelli bireyleri kapsamakta ve sadece bakıma muhtaç engelli aylığı verilmesi yoluyla olmaktadır. Kanun ile bu aylığa hak kazanmak da sıkı koşullara bağlanmaktadır. Bu nedenle, bu bireyler de gereken korumadan yararlanmakta zorlanmaktadırlar (Caniklioğlu ve Ünal, 2011, s.2285-2286).

2020 yılı Temmuz ayı ödeme döneminde, yaşlı ve engelli aylığı tutarları memur maaşlarına yapılan zamla birlikte artırılmıştır. Buna göre; yaşlı aylıklarının 711.50 TL'ye, yüzde 40-69 arası engelli aylıklarının 567.97 TL'ye, yüzde 70 ve üzeri engelli raporu olan vatandaşların aylıkları da 851.95 TL'ye yükseltilmiştir 5 .

\section{Evde bakım hizmetleri}

Bakıma muhtaç olan yaşlılara dönük bir uygulama olarak evde bakım hizmetlerinin verilmesidir. Bu hizmetin kapsamına da ağırlıklı olarak 65 yaş ve üzeri bakım gerektiren yaşlılar girmektedir (Taşçı, 2010, s. 185).

Evde bakım hizmeti, 10.03.2005 tarihli ve 25751 sayılı resmi gazetede yayınlanan "Evde Bakım Hizmetleri Sunumu Hakkında Yönetmelikte" düzenlenmiştir. Bu yönetmeliğin "Tanımlar" başlığını taşıyan 4. maddesine göre evde bakım hizmeti, "Hekimlerin tavsiyeleri doğrultusunda hasta kişilere, aileleri ile yaşadıkları ortamda, sağlı ekibi tarafından rehabilitasyon fizyoterapi, psikolojik tedavi de dahil tıbbi ihtiyaçlarını karşılayacak şekilde sağlık ve bakım ile takip hizmetlerinin sunulmasını" ifade eder (m.4/d). 
Türkiye'de evde bakım hizmetlerinin yürütümü ise Sağlık Bakanlığı tarafından 01.02.2010 tarihli 3895 sayılı resmi gazetede yayınlanan "Sağlık Bakanlı̆̆ınca Sunulan Evde Sağlık Hizmetlerinin Uygulama Usul ve Esasları Hakkında Yönerge 'de" düzenlenmiştir. Bu yönergenin amac1; "evde sağlık hizmeti sunumuna ihtiyacı olan bireylerin muayene, tetkik, tahlil, tedavi, tıbbi bakım ve rehabilitasyonlarını evinde ve aile ortaminda sağlanması, bu kişilere ve aile bireylerine sosyal ve psikolojik destek hizmetlerinin bir bütün olarak birlikte verilmesi için Sağhlk Bakanlı̆̆ına bağlı sağlık kurumları bünyesinde evde sağllk hizmetleri birimleri kurulması, bu birimlerin asgari fiziki donanımı ile araç, gereç ve personel standardının ve ilgili personelin görev yetki ve sorumluluklarının belirlenmesi, iletişim, uygulanacak randevu, kayıt ve takip sisteminin tanımlanması ve uygulamanın denetimine ilişkin usul ve esasların belirlenerek evde sağlık hizmetlerinin sosyal devlet anlayışı ile etkin ve ulaşılabilir bir şekilde uygulanmasını sağlamaktır" (m.1).

Yönergedeki tanıma göre, evde sağlı hizmeti ise “...Çeşitli hastalıklara bağlı olarak evde să̆lık hizmeti sunumuna ihtiyacı olan bireylere evinde ve aile ortamında sosyal ve psikolojik danışmanlik hizmetlerini de kapsayacak şekilde verilen muayene, tetkik, tahlil, tedavi, tıbbi bakım, takip ve rehabilitasyon hizmetleridir" (m.4/f).

Sağlık Bakanlığının bu hizmeti daha çok sağlık hizmetlerine odaklanırken yerel yönetimlerin de yaşlı ve engelli kişilere yönelik evde bakım hizmetleri verdiği görülmektedir. Bu hizmetler, belediyeden belediyeye farklılık göstermektedir. Bu hizmetlerin, evde sağlı hizmetinin yanında yaşlıya ayni ve nakdi yardım yapılması, evinin temizlenmesi, badana, boya ya da küçük onarımlarının yapılması, sosyal ve psikolojik destek verilmesi ve bazı belediyelerin yaşlı hizmet merkezleri vasıtasıyla çeşitli sosyal ve kültürel faaliyetler düzenlenerek yaşlıların bu hizmetlerden yararlanmalarının sağlanması şeklinde olduğu görülmektedir (Yıldırım ve Şahin, 2015, s. 72).

Evde bakım hizmetleri; kişilerin sağlığını korumak, yükseltmek, yeniden sağlığına kavuşturmak amacıyla verilen hizmetlerin profesyonel düzeyde veya aile bireyleri tarafından bireyin yaşadığı ortamda sunulmasıdır. $\mathrm{Bu}$ hizmetler, bireyin gereksinimi doğrultusunda yaşam kalitesini korumasını sağlamaktadır. Bu açıdan evde bakım hizmetleri genel olarak, kurum bakımının yerini alan, kurumlarda kalış gereksinimini azaltan ya da geciktiren hizmetlerdir (Oğlak, 2007, s. 101).

Evde bakım hizmetleri, üç temel özelliği bünyesinde barındırmaktadır. İlk olarak; evde bakım, yalnızca tıbbi hizmetlerin verilmesi değil, aynı zamanda bireyin gereksinim duyabileceği sosyal hizmetleri de içine almaktadır. İkinci olarak evde bakım, kısa süreli veya uzun süreli olarak sunulmaktadır. Evde bakıma ilişkin son özellik ise, evde bakıma ilişkin hizmet kapsamları çoğu kez birbirinden oldukça farklılık gösterebilmektedir (Özmete ve Hussein, 2017, s. 41).

\section{Kurumsal Bakım}

Türkiye'de yaşlılara yönelik sosyal hizmet kuruluşları; Bakım ve Rehabilitasyon Merkezleri, Özel Bakım Merkezleri, Aktif Yaşam Merkezleri, Huzurevleri, Huzurevi Yaşlı Bakım ve Rehabilitasyon Merkezleri, Hastaneler ve Ev Tipi Sosyal Hizmet Birimleri şeklinde sıralanabilir.

5799 sayılı Sosyal Hizmetler Kanunu'nun “ "Tanımlar" başlıklı 3. maddesine göre bakım ve rehabilitasyon merkezleri; "Bedensel, zihinsel ve ruhsal engellilikleri nedeniyle normal yaşamın gereklerine uymama durumunda olan bireylerin, fonksiyon kayıplarını gidermek ve toplum içinde kendi kendilerine yeterli olmasımı

\footnotetext{
${ }^{6}$ Daha önce 2828 sayılı “Sosyal Hizmetler ve Çocuk Esirgeme Kurumu Kanunu” olarak anılan bu Kanun'un adı 03.06.2011 tarihli ve 633 sayılı, Aile ve Sosyal Politikalar Bakanlığının Teşkilat ve Görevleri Hakkında Kanun Hükmünde Kararname ile 5799 sayılı "Sosyal Hizmetler Kanunu” olarak değiştirilmiştir. R.G., T.27.05.1983, S.18059.
} 
sağlayan beceriler kazandırmak veya bu becerileri kazanamayanlara devaml bakmak üzere kurulan sosyal hizmet kuruluşlarını" ifade eder (m.3/f-5).

16.08.2013 tarihli ve 29737 sayılı resmi gazetede yayınlanan “Bakıma Muhtaç Özürlülere Yönelik Özel Bakım Merkezleri Yönetmeliği” ile bakmakla yükümlü olunan birey sayısına göre kendilerine düşen ortalama aylık gelir tutarı, bir aylık net asgari ücret tutarının 2/3'ünden daha az olduğu tespit edilen bakıma muhtaç engellilerin ister ikametgâhlarında, isterse resmi veya özel bakım merkezlerinde bakımlarının sağlanması düzenlenmiştir (m.3). Bu Yönetmeliğin "Tanımlar" başlı̆̆ını taşıyan 4. maddesine göre özel bakım merkezi, "Bakıma muhtaç engelli kişilerin bakımı için yatılı veya gündüzlü hizmet veren, gerçek kişi ve özel hukuk tüzel kişileri tarafından açılan sosyal hizmet kuruluşu statüsündeki özel bakım kurumlarını" ifade eder (m.4/e).

Sosyal Hizmetler Kanunu'nun 3. maddesine göre aktif yaşam merkezi; "Engelli kişilerin, yaşam kalitesinin arttırılması ve sosyal hayata aktif katılımlarına katkı sağlamak amacıyla, engelli bireyle kişiler ile ailelerine rehberlik ve destek hizmeti ile evde gündüz bakım hizmeti sunan gündüzlü sosyal hizmet kuruluşlarını" ifade eder (m.3/f-9).

Sosyal Hizmetler Kanunu’nun 3. maddesine göre huzurevleri; “İhtiyacı olan yaşlı bireyleri huzurlu bir ortamda korumak ve bakmak, sosyal ve psikolojik ihtiyaçlarını karşılamak amacıyla kurulan yatılı sosyal hizmet kuruluşlarıdır” (m.3/f-4). Huzurevleri uzun süreli bakım ihtiyacı bulunan yaşlilara hizmet veren yatılı kuruluşlardır (Balcı-Gökçeoğlu, 2017, s. 55).

21.02.2001 tarihli 24325 sayılı resmi gazetede yayınlanan 2001 tarihli Huzurevleri ile Huzurevi Yaşlı Bakım ve Rehabilitasyon Merkezleri Yönetmeliği'nin 4. maddesine göre yaşlı bakım ve rehabilitasyon merkezi, "Yaşlı bireylerin yaşamların sağlı, huzur ve güven içinde sürdürmeleri amacıyla, kendi kendilerini idare edebilecek şekilde rehabilitasyonlarının sağlandığı, tedavisi mümkün olmayanların ise sürekli olarak özel bakım altına alındı̆̆ yatılı sosyal hizmet kuruluşunu" ifade eder (m.4/e).

Ülkemizde hastanelerde de bakım hizmeti verilmekle birlikte bu hizmetler sağlık sorununun türüne göre değişkenlik göstermekle birlikte daha kısa süreli olarak sunulmaktadır (Balc1-Gökçeoğlu, 2017, s. 55).

Sosyal Hizmetler Kanununa göre ev tipi sosyal hizmet birimleri ise; "çocuk, kadın, engelli ve yaşlılar ile bakım veya barınma ihtiyacı olan kişilere hizmet verilen mesken niteliğindeki yatıl sosyal hizmet birimlerini" ifade etmektedir (m.3/f-13).

\section{Bakıma Muhtaç Kişilere Yapılan Yardımların Finansmanı}

Türk Hukukunda bakıma muhtaçlık, sosyal yardımlar ve sosyal hizmetler kapsamında güvence altına alınmaya çalışılmaktadır. Ancak, bu güvencenin yeterli olduğunu söylemek mümkün değildir. Türkiye'de primsiz rejimden yapılan yardımlar hem miktar hem de yardımların yapılma şekli ve hak kazanımı bakımından yetersizdir.

Sosyal yardımlar ile bakıma muhtaç bireylerin güvence altına alınmasına ilişkin düzenlemelere 2022 sayılı 65 Yaşını Doldurmuş, Muhtaç, Güçsüz ve Kimsesiz Türk Vatandaşlarına Aylık Bağlanması Hakkında Kanunda yer verilmiştir. Bu Kanun ile yaşlılar bakımından sosyal yardım düzenlenmiş olmakla birlikte bu düzenlemeler bakıma muhtaçlık riski ile değil doğrudan yaşlılık olgusu ile ilişkilendirilmiştir. 65 yaşını doldurmuş kişiler diğer öngörülen koşulları da sağlamaları halinde bakıma muhtaç olmasalar bile bu Kanun kapsamında aylığa hak kazanabilmektedirler. Kanunda, bakıma muhtaç yaşlılar bakımından ayrıca bir koruma sağlanmaması bir eksikliktir. Çünkü bakıma muhtaçlık yaşlılık olgusu dışında ilave harcamaları gerektirmektedir. 2022 sayılı 
Kanunda bakıma muhtaçlık riskini güvence altına alan düzenlemeler de bulunmaktadır. Ancak, bu konudaki düzenlemeler bakıma muhtaç herkesi değil, sadece belirli bir grubu kapsamına almaktadır. Bu koruma sadece bakıma muhtaç engelli bireyleri kapsamakta ve sadece bakıma muhtaç engelli aylığı verilmesi yoluyla olmaktadır. Kanun ile bu aylığa hak kazanmak da sıkı koşullara bağlanmaktadır. Bu nedenle, bu bireyler de gereken korumadan yararlanmakta zorlanmaktadırlar (Caniklioğlu ve Ünal, 2011, s. 2285-2286). Ayrıca bu yardımların finansmanı genel vergilerle karşılandığı için siyasi iktidar tarafından her yıl belirli bir kaynağın bu aylıkların ödenmesi için tahsis edilmesini gerektirmektedir.

5510 sayılı Kanun kapsamında bakıma muhtaç kişilere yapılan yardımlar ise Kanun kapsamındaki sigortalıların ve işverenlerin ödedikleri primlerle finanse edilmektedir.

Kısa vadeli sigorta kollarının prim oranı, sigortalının prime esas kazancının \%2'sidir. Bu primin tamamını işveren öder. Cumhurbaşkanı bu oranı \%1,5 oranına düşürmeye ya da \%2,5 oranına yükseltmeye yetkilidir (6385 sayılı Kanunla değişik m.9/1, c). Malullük aylıklarının finansmanı için ise, sigortalının prime esas kazancının \%20'sidir. Bunun \%9'u sigortalı, \%11'i işveren payıdır (5510 sayılı SSGSSK m.81/1-a). Ancak toplanan bu primler sadece malullük aylıklarının finansmanı için değil aynı zamanda yaşlılık ve ölüm aylıklarının finansmanı için de kullanılmaktadır. Bakıma muhtaç kişilere yapılan sosyal yardımlar ise vergilerle finanse edilmektedir.

\section{Sonuç}

Doğum oranlarının giderek azalması, sağlık ve teknoloji alanında yaşanan gelişmeler, insanların daha bilinçli olması, refahın artması, ortalama yaşam süresinin ve nüfusun giderek yaşlanmasına neden olmaktadır. Nüfusun yaşlanması da sosyal, ekonomik ve toplumsal birçok sorunu da beraberinde getirmektedir. Nüfus yapısının değişmesine bağlı olarak sosyal güvenlik sitemlerinin aktif-pasif dengesi bozulmakta ve bir yandan gelirleri azalırken diğer yandan da giderleri artmaktadır. Bütün bunlara ilave olarak nüfusun yaşlanması ile beraber sağlık ve bakım maliyetleri giderek artmaktadır. Özellikle, beklenen yaşam sürelerinde meydana gelen artışla, nüfusun yaşlanmasına bağlı olarak günlük aktivitelerini yerine getiremeyen bireyler başkalarının bakımına ihtiyaç duymaktadırlar. Bakıma muhtaç kişilere bakacak yeterince bakım elemanının olmaması, bakım hizmetlerinin düşük kalitede olması, bakım hizmetlerinde çalışanların zor koşullarda, düşük ücretle ve genellikle kayıtışı çalışma koşulları altında çalışmaları ve istismara açık durumda olmaları küresel bir bakım krizine doğru yol açmaktadır. Bütün bunlara ilave olarak geniş aile yapısından çekirdek aileye dönüşüm, kadınların çalışma hayatına atılması nedeniyle temelde kadının görevi olarak görülen bakımın artık aile üyeleri tarafından yerine getirilmesinin zorlaşması gibi faktörler bakım sigortasının ülkemizde kurulması gerekliliğini ortaya koymaktadır.

Bakıma muhtaçlık olgusunun, Almanya örneğinde görülebileceği üzere güvence altına alınması kaçınılmaz olan başlı başına bir sosyal risk teşkil etmesi sebebiyle, ülkemizde de bakıma muhtaç kişilerin ekonomik durumlarından bağımsız olarak sosyal güvenlik sistemine dâhil edebilecek bir bakım güvence sistemine gereksinim duyulmaktadır. Ülkemizdeki sosyal hizmetler sisteminin, bakıma muhtaç kişilerin nüfus içindeki oranı dikkate alındığında bu kişilere yönelik bakım hizmeti sunmakta ve bu kişilerin korunma ihtiyacını karşılayan ailelerin desteklenmesi konusunda yetersiz kaldığı görülmektedir.

Dünya, ilk olarak Çin'in Wuhan bölgesinde, 2019 yılı Aralık ayının başında görülüp, tüm dünyayı etkisi altına alan ve pandemiye yol açan yeni koronavirüs enfeksiyonu ile karşı karşıya bulunmaktadır. Koronavirüs deve, yarasa, kedi gibi bazı hayvanlarda görülen ve hayvandan insana, insandan da insana bulaşabilen ve insanlar 
arasında da hastalık yapabilen bir virüs ailesidir. Çin'in Wuhan kentinde, deniz ürünleri ve canlı hayvan satan bir markette çalışan kişilerde ve daha sonrasında ise marketi ziyaret edenlerde akciğer rahatsızlıkları tespit edilmiştir. 7 Ocak 2020 tarihinde ise virüsün Koronavirüs ailesinden olduğu tespit edilmiş ve virüse WHO tarafından Yeni Coronavirus 2019 - COVID-19 (2019 n-CoV) adı verilmiştir (Üstün ve Özçiftçi, 2020, s. 143; Türkiye Eczacılar Birliği, 2020).

Başlangıçta sadece Çin'in bir bölgesinde olan virüs daha sonra tüm dünyaya hızlı bir şekilde yayılmış ve 11 Mart 2020'ye kadar neredeyse 114 ülkede vaka görüldüğünden ve 4000'den fazla insanın ölümüne yol açması nedeniyle WHO tarafından 11 Mart 2020 tarihinde pandemi ilan edilmiştir. Ülkemizde ise ilk COVID-19 vakası 11 Mart 2020 tarihinde görülmüştür (Çöl ve Güneş, 2020, s. 1). Ortaya çıkan bu pandemi nedeniyle neredeyse tüm dünyada yaşam durmuş, gerek toplumsal, gerek ekonomik gerekse de çalışma hayatı bu durumdan olumsuz yönde etkilenmiştir. İnsanlar bu pandemi dolayısıyla hastalanmakta, ölmekte ve çalışamaz hale gelmektedir. Doğal olarak COVID-19 nedeniyle hastalanan bireylerin kendisi ve ailesi bu durumdan olumsuz etkilenmekte geride kalanlar da psikolojik olarak olumsuz durumlar ortaya çıkabilmektedir. Covid19 en çok 65 yaş ve üzeri nüfusu etkilemektedir. Ülkemizde yaşlı nüfustaki artışla beraber bu grubun gerek sosyal hizmetlere gerekse de Covid-19 pandemisinde olduğu gibi yaşlı bakımına olan ihtiyacı artacaktır. Bu dönemde hem sağlık harcamaları yükseldiğinden hem de yaşlıların bakım ihtiyaçları daha da arttığından mevcut sistemle bunun sürdürülmesi sosyal güvenlik sistemlerini zora sokacaktır. Yaşlı bakım sigortası uygulamasına geçilmesi hem ülke ekonomisine hem de bakıma muhtaç yaşlılara büyük katkı sağlayacaktır. Örneğin koronavirüsten vaka sayısına göre en az ölümlerin olduğu Almanya'da temelde yaşlı bakım sigortasından evde bakım ve kurumsal bakım hizmetleri sunulmaktadır. Bu bağlamda bakım sigortası uygulamasının ivedilikle hayata geçirilmesi önemli bir tasarruf sağlayacaktır (Sağlam, 2020).

Sonuç olarak bakıma muhtaçlık da bir sosyal risk olması nedeniyle bu riske karşı da sosyal güvencenin sağlanması gerekmektedir. Bütün bu ortaya çıkan gelişmeler sonucunda ülkeler çeşitli yönlerden sosyal politika alanında düzenlemelere gitme ihtiyacı duymuşlardır. Ülkemizde de sosyal devlet olmanın gereği olarak sosyal yardımlar ve hizmetler bağlamında bakıma muhtaç engelli ve yaşlılara birçok hak sağlanmaktadır. Ancak sosyal yardımlar kendi elinde olmayan nedenlerle yoksul ve muhtaç duruma düşen bireylerine yönelik olduğundan toplumun tüm kesimlerini kapsamına almamaktadır. Bu bağlamda gerek merkezi yönetimin gerekse de yerel yönetimlerin sağladığı hizmetlerin hem kapsam hem de nitelik açısından yeterli olmaması nedeniyle bakım sigortasına ihtiyaç duyulmaktadır. Bu çerçevede de birçok ülkede yaşlılık sigortasında düzenlemeler yapılması gerekliliği ortaya çıkıı̧ ve bu sigorta kolunun yanında bakım sigortasının da varlığına ihtiyaç duyulmuştur. Dolayısıyla son yıllarda her ülke kendisi için ideal bakım sigortası sistemini oluşturma veya var olan sistemi iyileştirme çabası içine girmiştir. Bu gelişmeler ışı̆̆ında bakım sigortasının kurulması veya var olan sistemin iyileştirilmesi ülkelerin öncelikli konuları arasında yer alırken, etkili ve verimli bir bakım sigortası sistemi oluşturma ve bu sistemin finansal sürdürülebilirliğini sağlama en önemli sosyal politika meselelerinden biri haline gelmiştir. Ülkelerin etkili bir bakım sigortası sistemi oluşturma sürecinde karşılaştığı sorunların başında sistemin finansmanı, bu sigorta kolundan ne gibi hizmetlerin sağlanacağı gibi konular gelmektedir. Bu bağlamda ortaya çıkacak sorunlara yönelik olarak maliyeti düşük bakım hizmetlerine ihtiyaç duyulmaktadır.

Ülkemizde sonuç olarak bakıma muhtaçlık riskine karşı her bireyin güvence altına alınması ve bakıma muhtaçlığın sosyal sigorta sistemi içinde değerlendirilerek Sosyal Güvenlik Kurumu bünyesinde, "Bakım Sigortası" oluşturulması gerekmektedir. Sistemin bireylere bakıma muhtaçlık durumunda güvence sağlama karşılığında prim toplama esasına dayandırılması gerekmekte ve bu nedenle sistem, işçi, işveren ve devletin ödediği primlerle finanse edilmelidir. Bakım sigortasının kurulmasının işverenleri zor durumda bırakmaması için, prim oranlarının makul seviyelerde tutulması ve devlet katkısının da olması gerekmektedir. Sistemin 
finansmanına vergi gelirleri kullanılarak yapılacak desteğin sürekliliği de sağlanmalıdır. Sigorta sistemine dâhil olmayanlar için hizmetin devlet tarafından karşılanması sağlanmalıdır. Primlerin toplanması, denetim, organizasyon ve rehberlik hizmetlerinin yerine getirilmesinden Sosyal Güvenlik Kurumu sorumlu olmalı ve bu alana özel sigorta sisteminin de dâhil edilmesi gerekmektedir. Aile, Çalışma ve Sosyal Hizmetler Bakanlığı tarafından prim ödeyemeyecek durumda olan bakıma muhtaç vatandaşlara yapılan sosyal yardımlar ve sosyal hizmetler devam ettirilmelidir. Bütün bunlara ilave olarak Aile, Çalışma ve Sosyal Hizmetler Bakanlığı bünyesinde bir fon oluşturulmalı ve fonun değerlendirilmesi ile ilgili yatırım araçlarının nasıl kullanılacağına da karar verilmelidir.

Bakıma muhtaçlık kriteri, engelli, yaşlı ve hastalık durumuna göre belirlenmeli, bakıma muhtaçlık seviyeleri ve ihtiyaçlara göre hizmetler planlanmalıdır. Bakıma muhtaç durumda olanların kişisel mülkleri bakım sigortalarına aktarılmalıdır. Bu konuda, gerek merkezi ve yerel yönetimlere gerekse de sivil toplum kuruluşlarına önemli görevler düşmektedir. Bakım sigortası sistemi kurgulanırken ortaya çıabilecek ihtiyaçlara göre kamu sektörü ve özel sektör arasında sorumluluk aktarılmalıdır. Bakıma muhtaç kişiler için veri eksikliğini giderici araştırmalar yapılmalıdır. Bakım hizmetlerine ilişkin sağlık harcamalarının tespiti yapılmalıdır. Bakım hizmeti paketinde neler olacağı ve bunların fizibilite çalışmaları yapılmalıdır.

Engelliliğin ve bakıma muhtaçlı̆̆ın önlenmesi ve fon giderlerini azaltmaya yönelik olarak koruyucu ve önleyici tedbirlerin alınması ile beraber toplumun da bilinçlendirilmesi gerekmektedir. Yukarıda bahsettiğimiz öneriler dâhilinde oluşturulacak bakım sigortası ile tüm nüfusun bakıma muhtaçlık konusunda kapsama alınması sağlanarak, toplanacak primlerle de sistemin sürdürülebilirliği sağlanmış olacaktır.

\section{Kaynakça}

Ağören, V. (2009). Bakım sigortası ve Türkiye uygulaması. Ankara: Sosyal Güvenlik Kurumu.

Ağören, V. (2017). Bakım sigortası ve Türkiye için model önerisi. Sosyal Güvence Dergisi, 12 (6), 1-26. Erişim adresi: https://dergipark.org.tr/tr/pub/sosyalguvence/issue/31548/345758

Aile Çalışma ve Sosyal Hizmetler Bakanlığı. (2020). Engelli ve Yaşlı İstatistik Bülteni 2020-Ocak, 1-116 https://ailevecalisma.gov.tr/media/37313/istatistik-bulteni-ocak-2020-1.pdf (09.09.2020).

Aile, Çalışma ve Sosyal Hizmetler Bakanlı̆̆ı. (2020). Evde Bakım Ücretini 1.544 TL’ye Yükselttik https://www.ailevecalisma.gov.tr/tr-tr/haberler/bakan-selcuk-evde-bakim-ucretini-1-544-tl-yeyukselttik/ (13.09.2020).

Aile ve Sosyal Politikalar Bakanlığı Özürlü ve Yaşlı Hizmetleri Genel Müdürlüğü (2013). Bakım hizmetleri stratejisi ve eylem planı (2011-2013) kapsamında; sosyal güvenlik sisteminde; bakım güvence modeli ve bakım sigortası oluşturulması çalışmaları taslak raporu. Ankara. Erişim adresi: https://ailevecalisma.gov.tr/media/33773/bakim-hizmetleri-stratejisi-ve-eylem-plani-2011-2013.doc

Ayhan, B. (2014). Uzun süreli bakım sistemleri ve finansman yöntemleri: Türkiye açısından değerlendirme (Uzmanlık alan tezi). Engelli ve yaşlı hizmetleri genel müdürlügü, Ankara.

Balcı-Gökçeoğlu, Ş. (2017). Sosyal güvenlik hakkı açısından yaşlı bakımı. İstanbul: On İki Levha.

Bundesministerium fur Gesundheit, (2020). https://www.bundesgesundheitsministerium.de/fileadmin/Dateien/3_Downloads/Statistiken/Pflegever sicherung/Zahlen_und_Fakten/Zahlen_und_Fakten_der_SPV_Juli_2020_bf.pdf (06.09.2020). 
Bundesministreium für Gesundheith, 2020 http://www.sozialpolitik-aktuell.de/tl_files/sozialpolitikaktuell/_Politikfelder/Gesundheitswesen/Datensammlung/PDF-Dateien/abbVI41a.pdf (06.09.2020).

Caniklioğlu, N. ve Ünal, C. (2011). Karşılaştırmalı hukuk ışı̆̆ında Türk hukukunda bakım sigortasının kurulmasının gerekliliği. S. Başterzi (Ed.), Prof. Dr. Sarper Süzek’e Armağan, III, içinde (s. 2267-2297). İstanbul: Beta.

Cengiz, İ. (2018). Türk sosyal güvenlik sistemi içerisinde yaşlılara yönelik sosyal yardım ve sosyal hizmetler. Sosyal Güvenlik Dergisi, 8(2), 23-58. Erişim adresi: https://dergipark.org.tr/tr/download/articlefile/589721

Çağlar, T. (2015). Türkiye ve Almanya'da karşılaştırmalı yaşlı bakım model ve uygulamaları. (Yayınlanmamış doktora tezi). Hacettepe üniversitesi / sosyal bilimler enstitüsü, Ankara.

Çöl, M. ve Güneş, G. (2020). Covid-19 salginına genel bir bakış. O. Memikoğlu ve V. Genç (Ed.), Covid-19 içinde (s. 127-138). Ankara: Ankara Tip Fakültesi.

Danış, Z. ve Genç, Y. (2011). Kurumsal bakım elemanlarının genel özellikleri ve yaşadıkları sorunlar. Yalova Sosyal Bilimler Dergisi, 1(2), 170-183. Erişim adresi: https://dergipark.org.tr/tr/pub/yalovasosbil/issue/21786/615349.

Danış, Z. ve Solak, Y. (2014). Evde bakım hizmetlerinin organizasyonu: Hollanda örneği. The Journal Social Science Studies, 24, 57-71. Erişim https://arastirmax.com/en/system/files/dergiler/79201/makaleler/24/1/arastirmax-evde-bakimhizmetlerinin-organizasyonu-hollanda-ornegi.pdf (08.02.2019).

Demographic of Germany (2019). https://www.worldometers.info/world-population/germanypopulation/\#: :text=The\%20current\%20population\%20of\%20Germany,of\%20the\%20total\%20world\% 20population (07.09.2020).

Engelli ve Yaşlı Hizmetleri Genel Müdürlüğü (2020). Engelli ve Yaşlı İstatistik Bülteni 2020 - Ocak. https://ailevecalisma.gov.tr/media/37313/istatistik-bulteni-ocak-2020-1.pdf (13.02.2019).

European Commission (2017). Peer review on Germany's latest reforms of the long-term care system, Germany. Erişim adresi: https://ec.europa.eu/social/main.jsp?langId=en\&catId=89\&newsId=9008 (05.07.2019).

Geraedts, M.; Heller, G. V. ve Harrington, C. A. (2000). Germany's long-term-care insurance: Putting a social insurance model into practice. The Milbank Quarterly, 78 (3), 375-401. Erişim adresi: https://www.milbank.org/quarterly/articles/germanys-long-term-care-insurance-putting-a-socialinsurance-model-into-practice/ (10.03.2019).

Hekimler, A. (2015). Federal Almanya'da sosyal bakım sigortasının temel esasları, Çalışma ve Toplum, 44 (1), 45-76. Erişim adresi: https://www.calismatoplum.org/makale/federal-almanyada-sosyal-bakimsigortasinin-temel-esaslari--turkiye-icin-gozlemler

Hekimler, A. (2017). Yaşlılara yönelik bir sosyal politika aracı olarak bakım sigortası: Federal Almanya örneği. Ahi Evran Üniversitesi Sosyal Bilimler Enstitüsü Dergisi, 3 (2), 235-243. Erişim adresi: https://dergipark.org.tr/tr/pub/aeusbed/issue/33268/321912

Metin, M. (2014). Almanya Federal Cumhuriyeti'ndeki zorunlu bakım sigortası ve Türkiye'deki uygulanabilirliği. (Uzmanlık tezi). Dış ilişkiler ve yurtdışı işçi hizmetleri genel müdürlüğü, Ankara.

Oğlak, S. (2007). Uzun süreli evde bakım hizmetleri ve bakım sigortası, Turkish Journal of Geriatrics, 10 (2), 100-108. Erişim adresi: http://geriatri.dergisi.org/uploads/pdf/pdf_TJG_357.pdf

Oğlak, S. (2008). Evde bakım hizmetleri ve bakım sigortası (Ülke örnekleri ve Türkiye). (2.Baskı). İskenderun: İskenderun Belediyesi Kültür Yayınları.

Oğlak, S. (2011). Türkiye'de yaşlı bireylerin bakım gereksinimlerine yönelik yaşadığı ortamda sunulacak bakım

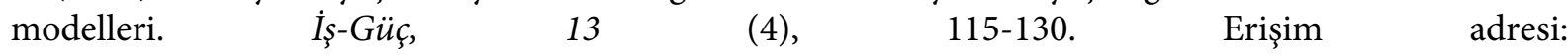
http://www.isguc.org/?p=article\&id=468\&cilt=13\&sayi $=4 \& y i l=2011$ 
Oğlak, S. (2014). Türkiye'de yaşlının uzun süreli bakımında bakım politikaları. N. Korkmaz, S. Yazıcı (Ed.), Küreselleşme ve Yaşlllık içinde (s. 215-234), Ankara: Ütopya.

Ökem, G. Z. ve Can, M. (2014). Avrupa birliği ülkelerinde yaşlilara yönelik uzun süreli bakım sistemleri ve uygulamaları. Ankara: Nobel.

Özgüler-Canbey, V. ( 2006). Yeni bir sosyal dışlanma biçimi olarak sayısal uçurum AB üyesi ülkelerde "e-içerme politikaları". Eskişehir: Nisan.

Özgüler-Canbey, V. (2016). Yeni teknolojiler ve Türkiye'de bilişim teknolojileri uygulamaları. V. Canbey Özgüler (Ed.), Yeni Teknolojiler ve Çalışma Hayatı içinde (s. 199-226). Eskişehir: Anadolu Üniversitesi.

Özmete, E. ve Hussein, S. (2017). Türkiye'de yaşl bakım hizmetleri raporu: Avrupa'dan en iyi uygulama örnekleri ve Türkiye için bir model tasarımı. Aile ve Sosyal Politikalar Bakanlığı Sosyal İçerme Politikaları Alanında Kurumsal Kapasitenin Artırılması Projesi. Ankara: TC Aile ve Sosyal Politikalar Bakanlığı. Erişim adresi: https://ailevecalisma.gov.tr/media/9334/tuerkiye-de-ya\%C5\%9Fl\%C4\%B1bak\%C4\%B1m-hizmetleri-avrupa-dan-en-iyi-uygulama-oernekleri-ve-tuerkiye-i\%C3\%A7in-birmodel-tasar\%C4\%B1m\%C4\%B1-proje-kitab\%C4\%B1.pdf (10.08.2020).

Pflegetagegeldversicherung. (t.y.). https://www.pflegeversicherung-infoportal.de/pflegeversicherung.html (09.09.2020).

Ranci, C. ve Pavolini, E. (2015). Not all that glitters is Gold: Long-term care reforms in the last two cecades in Europe. Journal of Social Policy, 25 (3), 270-285. Erişim adresi: https://journals.sagepub.com/doi/10.1177/0958928715588704

Sağlam, N. (2020). Yaşlı Bakım Sigortası Sistemi Pandemi Döneminde Yaşlılara ve Ekonomiye Büyük Katkı Sağlayacak. https://www.yasliyimhakliyim.com/yasli-bakim-sigortasi-sistemi-pandemi-donemindeyaslilara-ve-ekonomiye-en-buyuk-katkiyi-saglayacak/ (05.09.2020).

Şuözer, N. (2016, 1 Aralık). Almanya'da Bakım Sigortasında Çok Şey Değişecek. Artı 49. Erişim adresi: https://www.arti49.com/almanyada-bakim-sigortasinda-cok-sey-degisecek-630434h.htm, (08.02.2019).

Taşçı, F. (2010). Yaşlılara yönelik sosyal politikalar: İsveç, Almanya, İngiltere ve İtalya örneği. Çalışma ve Toplum, 24 (1), 175-202. Erişim adresi: https://www.calismatoplum.org/makale/yaslilara-yoneliksosyal-politikalar-isvec-almanya-ingiltere-ve-italya-ornekleri

Türkiye Eczacılar Birliği (2020). Coronavirüs Hakkında Bilinmesi Gerekenler, Erişim adresi: https://www.teb.org.tr/uploads/brosur/corona.pdf, (05.09.2020).

Türkiye İstatistik Kurumu (2018a). İstatistiklerle Gençler, 2017, Türkiye İstatistik Kurumu Haber Bülteni, Sayı: $27598 . \quad$ Erişim adresi: http://www.tuik.gov.tr/PreHaberBultenleri.do;jsessionid=pQvgh21RvF67LZxF9dmg10FHVnh0k7N5J GGJz39GQxtGCLqqbp2W!-453073999?id=27598, (22.03.2018).

Türkiye İstatistik Kurumu (2018b). İstatistiklerle Yaşlllar, 2017, Türkiye İstatistik Kurumu Haber Bülteni, Sayı: 27595. Erişim adresi: http://www.tuik.gov.tr/PreHaberBultenleri.do?id=27595, (22.03.2018).

Türkiye İstatistik Kurumu (2020a). İstatistiklerle Yaşlılar, 2019, Türkiye İstatistik Kurumu Haber Bülteni, Sayl: 33712. Erişim adresi: https://data.tuik.gov.tr/Bulten/Index?p=Istatistiklerle-Yaslilar-201933712\#: :text=T\%C3\%9C\%C4\%B0K\%20Kurumsal\&text=Ya\%C5\%9Fl\%C4\%B1\%20n\%C3\%BCfus\%20 olarak\%20kabul\%20edilen,9\%2C1'e\%20y\%C3\%BCkseldi.

Türkiye İstatistik Kurumu (2020b). İstatistiklerle Gençlik, 2019, Türkiye İstatistik Kurumu Haber Bülteni, Sayı: 33731. Erişim adresi: http://www.tuik.gov.tr/PreHaberBultenleri.do?id=33731, (07.09.2020).

United Nations. (2017). World Population Prospects. Erişim adresi: https://esa.un.org/unpd/wpp/Publications/Files/WPP2017_KeyFindings.pdf (13.09.2020).

United Nations. (2019). Ageing, https://www.un.org/en/sections/issues-depth/ageing/ (08.09.2020). 
Uyanık, Y. ve Başyiğit R. (2018). Demografik yapı içinde yaşlı nüfusun görünümü ve aktif yaşlanma yaklaşımı

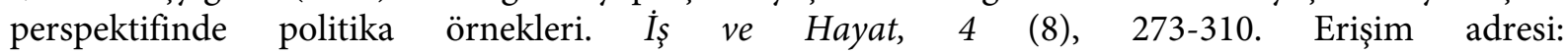
http://www.sekeris.org.tr/dergi/multimedia/dergi/113_demografik_yapi_icinde_yasli_nufusun_gorun umu_ve_aktif_yaslanma_yaklasimi_perspektifinde_politika_ornekleri.pdf

Üstün, Ç. ve Özçiftçi, S. (2020). Covid-19 Pandemisinin sosyal yaşam ve etik düzlem üzerine etkileri: Bir değerlendirme Çalışması, Anadolu Kliniği Tıp Bilimleri Dergisi, 25 (1), 142-153. Erişim adresi: https://dergipark.org.tr/tr/pub/anadoluklin/issue/53241/721864

World Health Organization (2008). Home care in Europe, R. Tarricone ve A. D. Tsouros, (Ed.), Milan, Italy. Erişim adresi: https://www.euro.who.int/_data/assets/pdf_file/0005/96467/E91884.pdf (04.09.2020).

Yakınların Bakımı. (2020). https://www.muenchen.info/soz/pdf/LHM_Pflege_angehoeriger_tuerkisch.pdf (08.09.2020).

Yıldırım, Ş. ve Şahin, F. (2015). Yaşlılık ve sosyal hizmet. H. Ceylan (Ed.), Modern Hayat ve Yaşlılık içinde (s. 55-96). Ankara: Nobel.

https://www.ailevecalisma.gov.tr/tr-tr/haberler/bakan-selcuk-evde-bakim-ucretini-1-544-tl-ye-yukselttik/ (13.09.2020)

https://www.sabah.com.tr/yasam/2020/10/15/evde-bakim-maasi-yatti-mi-hangi-illerde-yatirildi-14-ekimevde-bakim-maasi-yatan-iller-sorgulama-ekrani?paging=2 (15.10.2020). 